\title{
Biomimetic Charge Transfer Reactions at the Aqueous/Organic Solution Interface or through Artificial Membrane \\ Sorin KIHARA, ${ }^{a, *}$ Megumi KASUNO, ${ }^{b}$ Tomohiko OKUGAKI, ${ }^{c}$ Osamu SHIRAI, ${ }^{d}$ and Kohji MAEDA ${ }^{\mathrm{e}}$
}

\author{
a Kyoto Institute for Interesting Chemistry, 40-5 Sakuradani, Kamikazan, Yamashina, Kyoto 607-8466, Japan \\ b Department of Materials Chemistry, Faculty of Science and Technology, Ryukoku University, \\ Otsu, Shiga 520-2194, Japan \\ c Department of Energy and Hydrocarbon Chemistry, Graduate School of Engineering, Kyoto University, \\ Nishikyo, Kyoto 615-8510, Japan \\ d Division of Applied Life Sciences, Graduate School of Agriculture, Kyoto University, Sakyo, Kyoto 606-8502, Japan \\ e Department of Chemistry, Kyoto Institute of Technology, Matsugasaki, Sakyo, Kyoto 606-8585, Japan
}

* Corresponding author: kiharas-chem@zeus.eonet.ne.jp

\begin{abstract}
Some biomimetic reactions observed with the aid of aqueous/organic, W/O, two phases or liquid membrane, LM, systems were introduced. The reactions introduced were mostly those reported by the group of present authors as follows; (1) Transformations of porphyrin iron(III) complex, $\mathrm{Fe}(\mathrm{P})$, and a-tocopherol, a-TOH, derivatives in $\mathrm{O}$ contacted with $\mathrm{W}$. (2) The oxidation of $\mathrm{Fe}(\mathrm{P})$ in $\mathrm{O}$ with an oxidant in $\mathrm{W}$, a-TOH in $\mathrm{O}$ with nitric oxide in $\mathrm{W}$ or hydroquinone in $\mathrm{O}$ with oxygen in $\mathrm{W}$, and the reduction of quinone in $\mathrm{O}$ with $\beta$-nicotinamide adenine dinucleotide in W. (3) A respiration mimetic reaction accompanied by the selective ion transfer at the W/O interface. (4) Biomimetic charge transport reactions observed by LM systems such as the oscillation of membrane current. (5) A new type of membrane transport reaction realized in the presence of an applied electrical potential gradient parallel to the W/ membrane interface. The processes of above-described reactions were elucidated based on the voltammetric methods and concepts taking into account the properties common to both artificial LMs and biomembranes. A method proposed by present authors for the elucidation of the membrane transport process was also introduced.
\end{abstract}

(c) The Electrochemical Society of Japan, All rights reserved.

Keywords : Biomimetic Reactions, Aqueous/Organic Solution Interface, Liquid Membrane, Voltammetric Methods

\section{Introduction}

The biomembrane is composed of the fundamental structure formed by lipids (phospholipid, steroid, etc.) and other substances such as proteins and polysaccharides which locate in the membrane. It has been believed in the most of researches carried out so far that the latter mainly contributes to the appearance of various functions specific to biomembranes such as the energy transformation, material digestion, exchange of information, etc., but the contribution of the fundamental structure is not significant.

On the other hand, various works have been done in the field of electrochemistry assuming artificial membranes composed of organic solvents as simple models of biomembranes, ${ }^{1-6}$ and it has

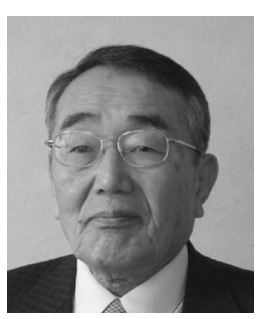

Sorin KIHARA is Professor Emeritus of Kyoto Institute of Technology. He is currently presiding Kyoto Institute for Interesting Chemistry. He received his B. Sci. in chemistry and D. Sci. in analytical chemistry in 1967 and 1974, respectively, from Kyoto University.

He was an associate member of IUPAC (Division of Electroanalytical Chemistry), the Editor-in-Chief of the official journal of Japan Society for Analytical Chemistry, "Bunseki", vice-president of Japan Society for Analytical Chemistry, and president of The Polarographic Society of Japan. The awards Kihara has received include the Japan Society for Analytical Chemistry Award (2002).

His current research interests lie in the area of chemical reactions unique to the aqueous/organic solution interface and electrochemical reactions of actinide elements. been found that various charge transfer reactions observed at artificial liquid membranes, LMs, closely resembled the reactions at biomembranes though the artificial LMs did not contain any proteins or polysaccharides.

The reason is attributable to the properties common to both of the artificial LM and the biomembrane as follows.

1. Both membranes are flexible and soft.

2. Both membranes dissolve hydrophobic chemical species well, and form an interface with an aqueous solution which dissolves hydrophilic species well.

3. At the interface, not only the ion transfer but also the electron transfer proceeds, and these charge transfer reactions often promote or restrain each other. In other words, the interface often works as the field of the energy exchange.

4. The neutral species such as $\mathrm{H}_{2} \mathrm{O}$ also transfer at the interface. For example, $\mathrm{H}_{2} \mathrm{O}$ produced by the reaction in the membrane transfers to the aqueous phase promoting the reaction in the membrane.

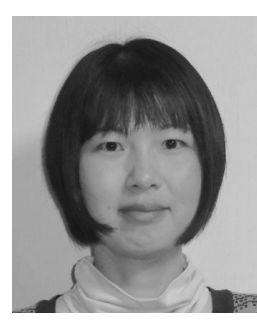

Megumi KASUNO is Lecturer at Ryukoku University (2010-present). She graduated from Department of Chemistry, Kyoto Institute of Technology in 1999, where she obtained her doctorate in 2005. She was engaged in National Institute of Advanced Industrial Science and Technology, and moved to the present address in 2006 .

Her research focuses on the development of methodologies in the field of electroanalytical chemistry and the electrochemical elucidation of reactions at liquid/liquid interfaces. 
5. A surfactant or an ion-pair adsorbs at the interface and promotes or disturbs the charge transfer at the interface.

6. The aqueous solution/membrane interface becomes ununiform by e.g., the adsorption.

7. Two aqueous solution/membrane interfaces exist in the membrane system, and the charge transfer reactions at two interfaces occur antagonistically each other under an applied membrane potential.

Since there are many properties common to artificial LMs and biomembranes as described above, the information obtained by the elucidation of reactions at artificial LMs might be useful for the better understanding of biomembrane phenomena.

In the present article, the reactions at LMs which resemble bioreactions at biomembranes are introduced choosing from works published by the group of the present authors, and the processes which realized the reactions are discussed with the aid of voltammetric methods and concepts.

\section{Methods for Measurements of Charge Transfer Reactions at the Aqueous/Organic Solution Interfaces and Identification of the Reactions}

The methods adopted for the elucidation of charge (ion or electron) transfer processes at the aqueous/organic solution, $\mathrm{W} / \mathrm{O}$, interface in most of works cited in the present article were polarography for charge transfer, PCTIES, at an aqueous electrolyte solution dropping electrode, ${ }^{7-9} \mathrm{AEDE}$, and voltammetry for charge transfer, VCTIES, at the stationary $\mathrm{W} / \mathrm{O}$ interface of an ordinary area ${ }^{10}$ or the micro W/O interface. ${ }^{11,12}$ These methods were applied to the investigation of the relation between potential difference, $E$, at the $\mathrm{W} / \mathrm{O}$ interface and the current, $I$, flowed across the interface. Controlled potential difference electrolysis at the W/O interface, ${ }^{13}$ CPDE, was carried out in the identification of the product of the interfacial charge transfer reaction. The cells used for PCTIES, VCTIES and CPDE were identical with those described in Refs. 9 to 13. The $\mathrm{O}$ adopted was nitrobenzene, NB, or 1,2-dichloroethane, DCE.

In PCTIES, VCTIES and CPDE, $E$ was applied as the potential of a silver-silver chloride electrode, SSE, in W referred to the potential of tetraphenylborate, $\mathrm{TPhB}^{-}$, or tetraethylammonium, $\mathrm{TEA}^{+}$, ion selective electrode, TPhBE or TEAE, in $\mathrm{O}$. The $E$ thus measured were converted to those of TPhE scale and presented in this paper. Here, $\mathrm{TPhE}$ is an imaginary potential where the transfer Gibbs energy corresponds to zero, and was defined under the extrathermodynamic assumption. ${ }^{14}$ The potentials of TPhBE and TEAE were determined to be $0.35_{0}{ }^{9}$ or $-0.05 \mathrm{~V}^{15}$ versus TPhE and $0.377^{16}$ or $0.01{ }_{9} \mathrm{~V}^{17}$ versus $\mathrm{TPhE}$ when $\mathrm{O}$ was $\mathrm{NB}$ or DCE, respectively.

The supporting electrolyte, $\mathrm{SE}$, added in $\mathrm{W}$ was $\mathrm{MgSO}_{4}, \mathrm{Li}_{2} \mathrm{SO}_{4}$ or $\mathrm{Na}_{2} \mathrm{SO}_{4}$, and that in $\mathrm{O}$ was a salt of a cation such as tetraphenylarsonium ion, $\mathrm{TPhAs}^{+}$, tetrapentyl ammonium ion, $\mathrm{TPenA}^{+}$, tetrahexylammonium ion, $\mathrm{THexA}^{+}$, tetradecylammonium ion, $\mathrm{TDA}^{+}$, bis(triphenylphosphoranylidene)ammonium ion,

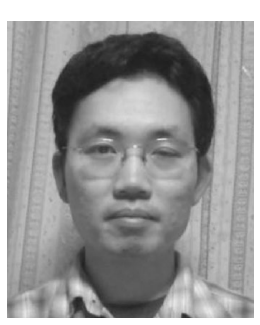

Tomohiko OKUGAKI is Research Associate of Graduate School of Engineering, Kyoto University (2011-present). He graduated from Department of Chemistry, Kyoto Institute of Technology in 2004, where he obtained his doctorate (Dr. Eng.) in 2009. $\mathrm{He}$ was engaged in Kyoto University and Kyoto Institute of Technology, and moved to the present address in 2011 .

His research fields are in Li-ion secondary battery and electrochemistry at the liquid/liquid interface. His current research interests lie in the area of the novel anode of Li-ion secondary batteries with higher capacity than that of conventional graphite.
$\mathrm{BTPPA}^{+}$, or crystalviolet ion, $\mathrm{CV}^{+}$, and an anion such as $\mathrm{TPhB}^{-}$, dipicrylaminate, $\mathrm{DPA}^{-}$, or tetrakis[3,5-bis(trifluoro methyl)phenyl]borate, $\mathrm{TFPB}^{-}$.

\section{Reactions in $\mathrm{O}$ in the Presence of a Contacted $\mathrm{W}$ and Those at the W/O Interface}

When $\mathrm{O}$ (regarded as LM) is contacted with W, not only charged species (ion and electron) but also neutral species transfer at the $\mathrm{W} / \mathrm{O}$ interface, realizing biomimetic reactions which do not proceed in $\mathrm{O}$ in the absence of the contacted W. The transfer of the ion of interest often couples with that of other kind of ion or that of electron due to the interfacial redox reaction occur, and the energy exchange proceeds at the interface.

In the following, examples of biomimetic reactions in $\mathrm{O}$ in the presence of $\mathrm{W}$ contacted with $\mathrm{O}$ are introduced.

\subsection{Transformation and reactions of porphyrin iron(III) derivatives in $\mathrm{O}$ at the $\mathrm{W} / \mathrm{O}$ interface ${ }^{16}$}

The $\mu$-oxo dimer, $[\mathrm{Fe}(\mathrm{P})]_{2} \mathrm{O}$, of a porphyrin iron(III) complex, $\mathrm{Fe}(\mathrm{P})$, is formed when $\mathrm{O}$ containing a hydrophobic $\mathrm{Fe}(\mathrm{P})$ such as chloro(octaethylporphyrinato)iron(III), $\mathrm{Fe}(\mathrm{OEP}) \mathrm{Cl}$, is shaken with $\mathrm{W}$ of high $\mathrm{pH}$. Though $[\mathrm{Fe}(\mathrm{P})]_{2} \mathrm{O}$ has not been found by structure analyses of cytochrome $c$ oxidase, $[\mathrm{Fe}(\mathrm{P})]_{2} \mathrm{O}$ had been regarded as a model compound of a heme protein in cytochrome $c$ oxidase since $[\mathrm{Fe}(\mathrm{P})]_{2} \mathrm{O}$ catalyzes the reduction of oxygen in $\mathrm{W} .{ }^{18}$ One of other unique features of $\mathrm{Fe}(\mathrm{P})$ is that the protonation of the $\mathrm{Fe}(\mathrm{P})$ derivatives proceeds much more easily when monomers of the derivatives are transformed to $[\mathrm{Fe}(\mathrm{P})]_{2} \mathrm{O}$ analogously to the protonation of the $\mu$-oxo dimer of the non-heme complex in hemerythrin or methane monooxygenase which facilitates the transportation of $\mathrm{H}^{+}$through a biomembrane. ${ }^{19,20}$

The transformation, protonation and oxidation reactions of $\mathrm{Fe}(\mathrm{OEP})$ derivatives in DCE made in contact with $\mathrm{W}$ of various $\mathrm{pH}$ were investigated as the function of $E$ by the group of present authors as follows, ${ }^{16}$ and it was found that the reactions resembled largely those in biological systems.

Voltammograms shown in Fig. 1 were measured at the micro interface between W and DCE of compositions as Eqs. (1) to (4). The SE added in $\mathrm{W}$ and DCE were $0.01 \mathrm{M}\left(=\operatorname{moldm}{ }^{-3}\right) \mathrm{Na}_{2} \mathrm{SO}_{4}$ and $10^{-3} \mathrm{M} \mathrm{BTPPA}^{+} \mathrm{TFPB}^{-}$, respectively.

\begin{tabular}{cc|cc} 
& $\mathrm{W}$ & $\mid$ & $\mathrm{DCE}$ \\
Curve 1 & $10^{-3} \mathrm{M} \mathrm{Cl}^{-}$and $0.5 \mathrm{M} \mathrm{H}_{2} \mathrm{SO}_{4}$. & $\mid 2.5 \times 10^{-4} \mathrm{M} \mathrm{Fe}(\mathrm{OEP}) \mathrm{Cl}$ & (1) \\
Curve 2 & $0.1 \mathrm{M} \mathrm{Cl}^{-}$and $0.5 \mathrm{M} \mathrm{H}_{2} \mathrm{SO}_{4}$. & $\mid 2.5 \times 10^{-4} \mathrm{M}[\mathrm{Fe}(\mathrm{OEP})]^{+}$ & (2) \\
Curve 3 & $\mathrm{pH}=3$ & $\mid 2.5 \times 10^{-4} \mathrm{M}[\mathrm{Fe}(\mathrm{OEP})]^{+}$ & (3) \\
Curve 4 & $\mathrm{pH}=3$ & $\mid 1.25 \times 10^{-4} \mathrm{M}[\mathrm{Fe}(\mathrm{OEP})]_{2} \mathrm{O}(4)$
\end{tabular}

Consulting with the products in W and DCE obtained by the CPDE, reactions responsible for current waves in curves were identified as follows;

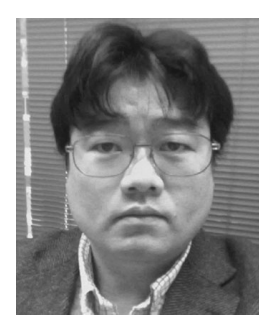

Osamu SHIRAI is Associate Professor of Graduate School of Agricultures (2006-present). He graduated from Osaka University in 1989. He passed through the doctoral course of Kyoto University, and he obtained his doctorate (Dr. Sci.) in 1997. He joined Japan Atomic Energy Research Institute, and was engaged in research and development on pyrochemical reprocess of spent nuclear fuels (1995-2003). He moved to Kyoto University Research Reactor Institute as Associate Professor (2003-2006). He transferred to Graduate School of Agriculture in 2006.

His current research interests lie in the area of charge transport across artificial membranes, energy transformation by coupling between ion transport and electron transport and transmission of a change in the membrane potential. 


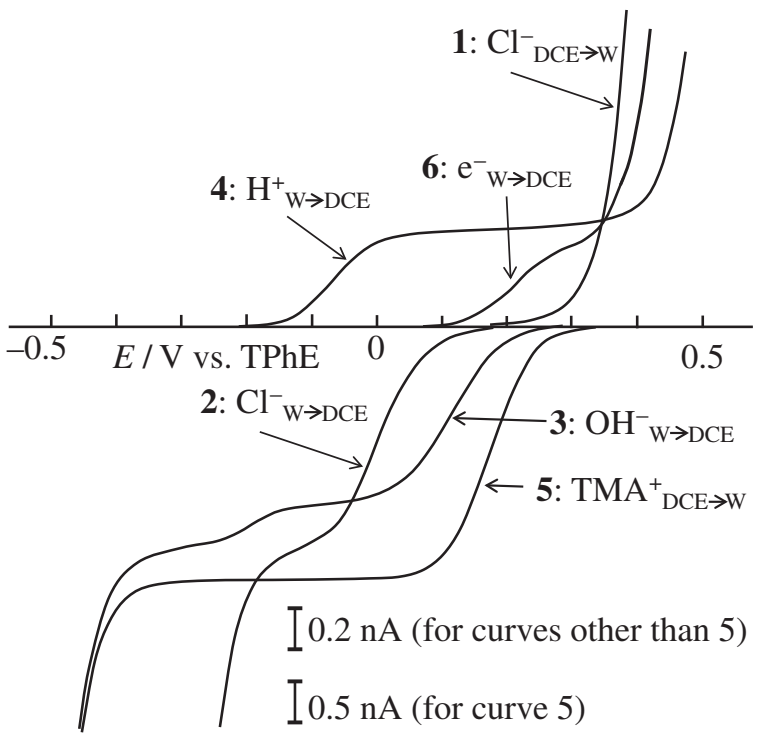

Figure 1. Voltammogram for ion or electron transfer at the micro $\mathrm{W} / \mathrm{DCE}$ interface in the presence of $\mathrm{Fe}(\mathrm{OEP})$ derivative in DCE. Curve 1: transfer of $\mathrm{Cl}^{-}$of $2.5 \times 10^{-4} \mathrm{M} \mathrm{Fe}(\mathrm{OEP}) \mathrm{Cl}$ from DCE to W containing $10^{-3} \mathrm{M} \mathrm{Cl}^{-}$and $0.5 \mathrm{M} \mathrm{H}_{2} \mathrm{SO}_{4}$. Curve 2: transfer of $\mathrm{Cl}^{-}$from $\mathrm{W}$ containing $0.1 \mathrm{M} \mathrm{Cl}^{-}$and $0.5 \mathrm{M} \mathrm{H}_{2} \mathrm{SO}_{4}$ to $\mathrm{DCE}$ facilitated by $2.5 \times 10^{-4} \mathrm{M}[\mathrm{Fe}(\mathrm{OEP})]^{+}$in DCE. Curve 3: transfer of $\mathrm{OH}^{-}$from $\mathrm{W}$ of $\mathrm{pH}=3$ facilitated by $2.5 \times 10^{-4} \mathrm{M}[\mathrm{Fe}(\mathrm{OEP})]^{+}$ in DCE. Curve 4: transfer of $\mathrm{H}^{+}$from $\mathrm{W}$ of $\mathrm{pH}=3$ to DCE facilitated by $1.25 \times 10^{-4} \mathrm{M}[\mathrm{Fe}(\mathrm{OEP})]_{2} \mathrm{O}$ in DCE. Curve 5: transfer of $\mathrm{TMA}^{+}$from DCE containing $5 \times 10^{-4} \mathrm{M} \mathrm{TMA}^{+} \mathrm{TFPB}^{-}$ to W. Curve 6: electron transfer from $0.01 \mathrm{M}\left[\mathrm{W}(\mathrm{CN})_{8}\right]^{3-}$ in $\mathrm{W}$ of $\mathrm{pH}=10$ to $1.25 \times 10^{-4} \mathrm{M}[\mathrm{Fe}(\mathrm{OEP})]_{2} \mathrm{O}$ in DCE.

Curve 1: Transfer of $\mathrm{Cl}^{-}$produced by the dissociation of $\mathrm{Fe}(\mathrm{OEP}) \mathrm{Cl}$ from DCE to W.

$$
\begin{aligned}
& \mathrm{Fe}(\mathrm{OEP}) \mathrm{Cl}_{\mathrm{DCE}} \rightleftarrows[\mathrm{Fe}(\mathrm{OEP})]^{+}{ }_{\mathrm{DCE}}+\mathrm{Cl}^{-}{ }_{\mathrm{DCE}} \\
& \mathrm{Cl}^{-}{ }_{\mathrm{DCE}} \rightarrow \mathrm{Cl}^{-}{ }_{\mathrm{W}}
\end{aligned}
$$

Here, the subscript indicates the phase where the species exists. Curve 2: Transfer of $\mathrm{Cl}^{-}$from $\mathrm{W}$ to DCE facilitated by $[\mathrm{Fe}(\mathrm{OEP})]^{+}$ in DCE [backward reactions of Eqs. (5) with (6)].

Curve 3: Transfer of $\mathrm{OH}^{-}$from $\mathrm{W}$ of $\mathrm{pH}=3$ to DCE facilitated by $[\mathrm{Fe}(\mathrm{OEP})]^{+}$in DCE.

$$
\begin{aligned}
& \mathrm{OH}^{-}{ }_{\mathrm{W}} \rightarrow \mathrm{OH}^{-}{ }_{\text {DCE }} \\
& {[\mathrm{Fe}(\mathrm{OEP})]^{+}{ }_{\text {DCE }}+\mathrm{OH}^{-}{ }_{\text {DCE }} \rightleftarrows \mathrm{Fe}(\mathrm{OEP}) \mathrm{OH}_{\mathrm{DCE}}}
\end{aligned}
$$

The $\mathrm{Fe}(\mathrm{OEP}) \mathrm{OH}$ in DCE dimerizes easily through the dehydration forming $\mu$-oxo dimer, $[\mathrm{Fe}(\mathrm{OEP})]_{2} \mathrm{O}$, since $\mathrm{H}_{2} \mathrm{O}$ produced in DCE is excluded to $\mathrm{W}$.

$$
2 \mathrm{Fe}(\mathrm{OEP}) \mathrm{OH}_{\mathrm{DCE}} \rightleftarrows[\mathrm{Fe}(\mathrm{OEP})]_{2} \mathrm{O}_{\mathrm{DCE}}+\mathrm{H}_{2} \mathrm{O}_{\mathrm{DCE}}
$$

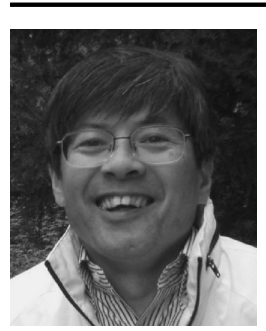

Kohji MAEDA is Professor of Department of Chemistry, Kyoto Institute of Technology (2007present). He graduated from Faculty of Science, Kyoto University in 1983, where he obtained his doctorate in 1991. He was engaged in Kobe University and Fukui Prefectural University, and moved to the present address in 1996. His research fields are in analytical chemistry and electrochemistry.

The recent main topic is the propagation of potential oscillation in liquid membrane systems.

Maeda has filled board members in such academic societies as The Japan Society of Analytical Chemical Society and The Polarographic Society of Japan as well as Kansai Branch of The Electrochemical Society of Japan.
Curve 4: Transfer of $\mathrm{H}^{+}$from $\mathrm{W}$ of $\mathrm{pH}=3$ to DCE facilitated by $[\mathrm{Fe}(\mathrm{OEP})]_{2} \mathrm{O}$ in DCE.

$$
\begin{aligned}
& \mathrm{H}^{+}{ }_{\mathrm{W}} \rightarrow \mathrm{H}^{+}{ }_{\text {DCE }} \\
& {[\mathrm{Fe}(\mathrm{OEP})]_{2} \mathrm{O}_{\mathrm{DCE}}+\mathrm{H}^{+}{ }_{\text {DCE }} \rightleftarrows[\mathrm{Fe}(\mathrm{OEP})]_{2} \mathrm{OH}^{+}{ }_{\text {DCE }}}
\end{aligned}
$$

Since the $E$ region for the positive current wave in curve 4 overlaps on that for the negative current wave in curve 3 when $\mathrm{pH}$ of $\mathrm{W}$ is 3 , the reaction of Eq. (7) couples with the reaction of Eq. (10), cancelling a part of the negative current of curve 3 .

The $E$ range for the negative current wave in curve 3 due to the reaction of Eq. (7) shifted about $0.06 \mathrm{~V}$ to more positive with the increase of $\mathrm{pH}$ of $\mathrm{W}$, and the range overlapped greatly with that available for curve 1 due to the reaction of Eq. (6) when $\mathrm{pH}$ of $\mathrm{W}$ was high as 11 indicating that the exchange of $\mathrm{Cl}^{-}$of $\mathrm{Fe}(\mathrm{OEP}) \mathrm{Cl}$ in DCE for $\mathrm{OH}^{-}$transferred from $\mathrm{W}$ proceeds spontaneously producing $\mathrm{Fe}(\mathrm{OEP}) \mathrm{OH}$ and then $[\mathrm{Fe}(\mathrm{OEP})]_{2} \mathrm{O}$. This is the reason why $[\mathrm{Fe}(\mathrm{OEP})]_{2} \mathrm{O}$ is formed when $\mathrm{O}$ containing $\mathrm{Fe}(\mathrm{OEP}) \mathrm{Cl}$ is shaken with $\mathrm{W}$ of high $\mathrm{pH}$.

When a cation such as tetramethylammonium ion, $\mathrm{TMA}^{+}$, was added in DCE in addition to $\mathrm{Fe}(\mathrm{OEP}) \mathrm{Cl}$, and shaken with $\mathrm{W}$, the product in DCE was found to depend on $\mathrm{pH}$ of $\mathrm{W}$, which can be explained by using charge transfer voltammograms in Fig. 1.

Curve 5 in Fig. 1 is the voltammogram for the transfer of $\mathrm{TMA}^{+}$ from DCE containing $5 \times 10^{-4} \mathrm{M} \mathrm{TMA}^{+} \mathrm{TFPB}^{-}$to $\mathrm{W}$.

$$
\mathrm{TMA}^{+}{ }_{\mathrm{DCE}} \rightarrow \mathrm{TMA}^{+} \mathrm{W}
$$

When $\mathrm{pH}$ of $\mathrm{W}$ is lower than 3 , the transfer of $\mathrm{Cl}^{-}$from DCE to $\mathrm{W}$ producing $[\mathrm{Fe}(\mathrm{OEP})]^{+}$couples with the transfer of $\mathrm{TMA}^{+}$from $\mathrm{DCE}$ to $\mathrm{W}$ though the transfer of $\mathrm{OH}^{-}$from $\mathrm{W}$ to DCE does not. Therefore, the product is $[\mathrm{Fe}(\mathrm{OEP})]^{+}$

When $\mathrm{pH}$ of $\mathrm{W}$ is between 3 and 11 , both the transfer of $\mathrm{Cl}^{-}$ from $\mathrm{DCE}$ to $\mathrm{W}$ producing $[\mathrm{Fe}(\mathrm{OEP})]^{+}$and that of $\mathrm{OH}^{-}$from $\mathrm{W}$ to DCE producing $\mathrm{Fe}(\mathrm{OEP}) \mathrm{OH}$ couple with the transfer of $\mathrm{TMA}^{+}$from $\mathrm{DCE}$ to $\mathrm{W}$. $\mathrm{Fe}(\mathrm{OEP}) \mathrm{OH}$ dimerizes spontaneously producing $[\mathrm{Fe}(\mathrm{OEP})]_{2} \mathrm{O}$, and the transfer of $\mathrm{H}^{+}$from $\mathrm{W}$ to DCE facilitated by $[\mathrm{Fe}(\mathrm{OEP})]_{2} \mathrm{O}$ producing $[\mathrm{Fe}(\mathrm{OEP})]_{2} \mathrm{OH}^{+}$also couples with the transfer of $\mathrm{TMA}^{+}$from DCE to W. Therefore, the product is $[\mathrm{Fe}(\mathrm{OEP})]_{2} \mathrm{OH}^{+}$.

When $\mathrm{pH}$ of W is higher than 11 , though both the transfer of $\mathrm{Cl}^{-}$ from DCE to W producing $[\mathrm{Fe}(\mathrm{OEP})]^{+}$and the transfer of $\mathrm{OH}^{-}$ from $\mathrm{W}$ to $\mathrm{DCE}$ producing $\mathrm{Fe}(\mathrm{OEP}) \mathrm{OH}$ couple with the transfer of $\mathrm{TMA}^{+}$from DCE to $\mathrm{W}$, the transfer of $\mathrm{H}^{+}$from $\mathrm{W}$ to $\mathrm{DCE}$ facilitated by $[\mathrm{Fe}(\mathrm{OEP})]_{2} \mathrm{O}$ does not couple. Therefore, the product is $[\mathrm{Fe}(\mathrm{OEP})]_{2} \mathrm{O}$.

Since $\mathrm{Fe}(\mathrm{P})$ derivatives in a biomembrane are considered to participate in the scavenging of oxidants in $\mathrm{W}$, the interfacial oxidation of a $\mathrm{Fe}(\mathrm{OEP})$ derivative in DCE by an oxidant in $\mathrm{W}$ was investigated by adopting $\left[\mathrm{W}(\mathrm{CN})_{8}\right]^{3-}$ as the oxidant.

Voltammograms were investigated at the micro interface between W containing $0.01 \mathrm{M}\left[\mathrm{W}(\mathrm{CN})_{8}\right]^{3-}$ and DCE containing $2.5 \times$ $10^{-4} \mathrm{M}$ Fe(OEP)Cl, $2.5 \times 10^{-4} \mathrm{M} \quad[\mathrm{Fe}(\mathrm{OEP})]^{+}, \quad 1.25 \times 10^{-4} \mathrm{M}$ $[\mathrm{Fe}(\mathrm{OEP})]_{2} \mathrm{O}$ or $1.25 \times 10^{-4} \mathrm{M}[\mathrm{Fe}(\mathrm{OEP})]_{2} \mathrm{OH}^{+}$. A positive current wave attributable to the interfacial redox reaction was observed (curve 6 in Fig. 1) when $\mathrm{W}$ of $\mathrm{pH}=10$ and DCE containing $[\mathrm{Fe}(\mathrm{OEP})]_{2} \mathrm{O}$ were adopted. Here, 10 is the $\mathrm{pH}$ where neither the formation of $[\mathrm{Fe}(\mathrm{OEP})]_{2} \mathrm{OH}^{+}$due to the transfer of $\mathrm{H}^{+}$ from $\mathrm{W}$ to $\mathrm{DCE}$ facilitated by $[\mathrm{Fe}(\mathrm{OEP})]_{2} \mathrm{O}$ nor the spontaneous reduction of $\left[\mathrm{W}(\mathrm{CN})_{8}\right]^{3-}$ by $\mathrm{H}_{2} \mathrm{O}$ are significant. Consulting with the products in $\mathrm{W}$ and DCE after CPDE at $E$ available for the limiting current of curve 6 , the interfacial redox reaction was expressed as,

$$
\begin{aligned}
& {\left[\mathrm{W}(\mathrm{CN})_{8}\right]^{3-}{ }_{\mathrm{W}}+[\mathrm{Fe}(\mathrm{OEP})]_{2} \mathrm{O}_{\mathrm{DCE}}} \\
& \quad \rightarrow\left[\mathrm{W}(\mathrm{CN})_{8}\right]^{4-}{ }_{\mathrm{W}}+[\mathrm{Fe}(\mathrm{OEP})]_{2} \mathrm{O}^{+}{ }_{\mathrm{DCE}}
\end{aligned}
$$

This result indicates that the transfer of electron from $[\mathrm{Fe}(\mathrm{OEP})]_{2} \mathrm{O}$ in DCE to $\left[\mathrm{W}(\mathrm{CN})_{8}\right]^{3-}$ in W proceeds more easily than the transfer 
of $\mathrm{H}^{+}$facilitated by $[\mathrm{Fe}(\mathrm{OEP})]_{2} \mathrm{O}$ when $\mathrm{pH}$ of $\mathrm{W}$ is 10 , and the bonding between $\mathrm{H}^{+}$and $[\mathrm{Fe}(\mathrm{OEP})]_{2} \mathrm{O}^{+}$is much weaker than that between $\mathrm{H}^{+}$and $[\mathrm{Fe}(\mathrm{OEP})]_{2} \mathrm{O}$.

When the voltammogram was measured by adopting $\mathrm{W}$ of $\mathrm{pH}$ lower than 6 , the positive current wave due to the electron transfer disappeared, but the positive current wave due to the facilitated transfer of $\mathrm{H}^{+}$was observed instead. This result indicates that the transfer of $\mathrm{H}^{+}$from $\mathrm{W}$ to DCE facilitated by $[\mathrm{Fe}(\mathrm{OEP})]_{2} \mathrm{O}$ occurs more easily than the transfer of electron when $\mathrm{pH}$ of $\mathrm{W}$ is lower than 6 , and the oxidation of $[\mathrm{Fe}(\mathrm{OEP})]_{2} \mathrm{OH}^{+}$produced by the transfer of $\mathrm{H}^{+}$proceeds less easily than $[\mathrm{Fe}(\mathrm{OEP})]_{2} \mathrm{O}$.

The results described in this section indicate the antagonistic occurrence of transfers of electron and $\mathrm{H}^{+}$can be controlled by selecting $\mathrm{pH}$ of $\mathrm{W}$.

In Ref. 16, the reaction observed at the interface between $\mathrm{W}$ of various $\mathrm{pH}$ and DCE containing chloro(tetraphenylporphyrinato)iron(III) was also discussed.

\subsection{Redox reactions between NO in $\mathrm{W}$ and $\alpha$-tocopherol in DCE $^{17}$}

Nitric oxide, NO, combines with superoxide producing peroxynitrite, $\mathrm{ONOO}^{-}$, and induces the peroxidation of lipids. The $\alpha$ tocopherol, $\alpha-\mathrm{TOH}$, which is the major component among eight derivatives of vitamin $\mathrm{E}$ works as an effective antioxidant in biological systems. $\alpha-\mathrm{TOH}$ reacts with $\mathrm{NO}$, and prevents the peroxidation of lipids in biological membranes.

The oxidation products of $\alpha-\mathrm{TOH}$ that have been detected in living bodies ${ }^{21,22}$ are $\alpha$-tocopheryl quinone, $\alpha$-TQ, and $\alpha$-tocopherol spiro-dimmer, $\alpha$-TD. On the other hand, the main product of electrode oxidation of $\alpha-\mathrm{TOH}$ at a platinum electrode was found to be $\alpha$-tocopherol cation radical, $\alpha$ - $\mathrm{TOH}^{+\cdot}$, in dichloromethane ${ }^{23}$ of which dielectric constant, $\varepsilon$, is relatively small $(\varepsilon=7.8)$ similarly to that of a bilayer lipid membrane. Here, $\alpha-\mathrm{TOH}^{+}{ }^{\bullet}$ is the one-electron oxidation product of $\alpha$-TOH. $\alpha$-TQ is the hydration product of $\alpha$ tocopherone cation, $\alpha-\mathrm{TO}^{+}$, produced from $\alpha-\mathrm{TOH}^{+\bullet}$ through the dissociation of $\mathrm{H}^{+}$followed by the one-electron oxidation. $\alpha$-TD is a dimmer of quinone methide, $\alpha-\mathrm{QM}$, produced from $\alpha-\mathrm{TO}^{+}$through the dissociation of $\mathrm{H}^{+}$.

The oxidation of $\alpha-\mathrm{TOH}$ in DCE with NO in W was investigated by the group of present authors, ${ }^{17}$ and the oxidation product of $\alpha$ $\mathrm{TOH}$ was confirmed to be $\alpha$-TQ analogously to that in a bio-system. The following is the simplified explanation of the oxidation process of $\alpha-\mathrm{TOH}$ at the W/DCE interface.

Since the formal potential, $E_{\mathrm{W}}{ }^{\prime \prime}$, for the reaction of Eq. (14) in W $(+1.59 \mathrm{~V}$ versus $\mathrm{SHE})$ is much more positive than that, $E_{\mathrm{DCE}}{ }^{\circ \prime}$, for the reaction of Eq. (15) in DCE $(+1.13 \mathrm{~V}$ versus $\mathrm{SHE})$, the interfacial redox reaction between $\mathrm{NO}$ in $\mathrm{W}$ and $\alpha-\mathrm{TOH}$ in DCE is estimated to proceed easily producing $\mathrm{N}_{2} \mathrm{O}$ and $\alpha-\mathrm{TOH}^{+}$.

$$
\begin{aligned}
& 2 \mathrm{NO}_{\mathrm{W}}+2 \mathrm{H}^{+}{ }_{\mathrm{W}}+2 \mathrm{e}^{-} \rightleftarrows \mathrm{N}_{2} \mathrm{O}_{\mathrm{W}}+\mathrm{H}_{2} \mathrm{O}_{\mathrm{W}} \\
& \alpha-\mathrm{TOH}_{\mathrm{DCE}} \rightleftarrows \alpha-\mathrm{TOH}^{+\cdot}{ }_{\text {DCE }}+\mathrm{e}^{-}
\end{aligned}
$$

The further oxidation of $\alpha-\mathrm{TOH}^{+\bullet}$ in DCE by NO in $\mathrm{W}$ is considered to be difficult since the oxidation potential of $\alpha-\mathrm{TOH}^{+\bullet}$ in DCE was so positive that any waves due to the further oxidation was not observed at a platinum electrode. When DCE is contacted with W, however, the dissociation of $\mathrm{H}^{+}$from $\alpha-\mathrm{TOH}^{+\bullet}$ in DCE proceeds since $\mathrm{H}^{+}$produced in DCE is hydrophilic, and hence transfers easily to $\mathrm{W}$. The dissociation product was estimated to be $\alpha-\mathrm{TO}^{*}$ consulting with that in acetonitrile. ${ }^{24}$

$$
\begin{aligned}
& \alpha-\mathrm{TOH}^{+\cdot}{ }_{\mathrm{DCE}} \rightarrow \alpha-\mathrm{TO}^{\circ}{ }_{\mathrm{DCE}}+\mathrm{H}^{+}{ }_{\mathrm{DCE}} \\
& \mathrm{H}^{+}{ }_{\mathrm{DCE}} \rightarrow \mathrm{H}^{+}{ }_{\mathrm{W}}
\end{aligned}
$$

The oxidation of $\alpha-\mathrm{TO}^{*}$ to $\alpha-\mathrm{TO}^{+}$is estimated to occur about $0.6 \mathrm{~V}$ more easily than that of $\alpha-\mathrm{TOH}^{+\bullet}$ consulting with the oxidation of $\alpha$-TOH in acetonitrile. ${ }^{25}$ Therefore, $\alpha-\mathrm{TOH}$ is oxidized to $\alpha-\mathrm{TO}^{+}$at the $E$ available for reactions of Eqs. (15) and (17).

$$
\begin{aligned}
& \alpha-\mathrm{TO}^{\circ}{ }_{\mathrm{DCE}} \rightarrow \alpha-\mathrm{TO}^{+}{ }_{\mathrm{DCE}}+\mathrm{e}^{-} \\
& \alpha-\mathrm{TOH}_{\mathrm{DCE}} \rightarrow \alpha-\mathrm{TO}^{+}{ }_{\mathrm{DCE}}+\mathrm{H}^{+}{ }_{\mathrm{DCE}}+2 \mathrm{e}^{-}
\end{aligned}
$$

The above consideration indicates that reaction of Eq. (19) proceeds together with reaction of Eq. (14) realizing the interfacial redox reaction.

$$
\begin{aligned}
& \alpha-\mathrm{TOH}_{\mathrm{DCE}}+2 \mathrm{NO}_{\mathrm{W}}+2 \mathrm{H}^{+}{ }_{\mathrm{W}} \\
& \quad \rightarrow \alpha-\mathrm{TO}^{+}{ }_{\mathrm{DCE}}+\mathrm{H}^{+}{ }_{\mathrm{DCE}}+\mathrm{N}_{2} \mathrm{O}_{\mathrm{W}}+\mathrm{H}_{2} \mathrm{O}_{\mathrm{W}}
\end{aligned}
$$

The hydrolysis of $\alpha-\mathrm{TO}^{+}$by water dissolved in DCE proceeds generating $\alpha$-TQ.

$$
\alpha-\mathrm{TO}^{+}{ }_{\mathrm{DCE}}+\mathrm{H}_{2} \mathrm{O}_{\mathrm{DCE}} \rightarrow \alpha-\mathrm{TQ}_{\mathrm{DCE}}+\mathrm{H}^{+}{ }_{\mathrm{DCE}}
$$

Not only the hydrolysis of $\alpha-\mathrm{TO}^{+}$in DCE but also that in W occurs since $\alpha-\mathrm{TO}^{+}$which has a charge transfers easily from DCE to W.

$$
\begin{aligned}
& \alpha-\mathrm{TO}^{+}{ }_{\mathrm{DCE}} \rightarrow \alpha-\mathrm{TO}^{+}{ }_{\mathrm{W}} \\
& \alpha-\mathrm{TO}^{+}{ }_{\mathrm{W}}+\mathrm{H}_{2} \mathrm{O}_{\mathrm{W}} \rightarrow \alpha-\mathrm{TQ}_{\mathrm{W}}+\mathrm{H}^{+}{ }_{\mathrm{W}}
\end{aligned}
$$

The $\alpha$-TQ produced in $\mathrm{W}$ is neutral, and hence transfers to DCE easily.

$$
\alpha-\mathrm{TQ}_{\mathrm{W}} \rightarrow \alpha-\mathrm{TQ}_{\mathrm{DCE}}
$$

In Ref. 17, the spontaneous redox reaction of $\mathrm{NO}$ in $\mathrm{W}$ with $\alpha-\mathrm{TOH}$ in DCE and the generation of $\alpha$-TD observed when $\alpha-\mathrm{TOH}$ in DCE was oxidized by $\mathrm{MnO}_{4}^{-}$(adopted as a substitute for $\mathrm{ONOO}^{-}$) in $\mathrm{W}$ were discussed, though they are omitted here.

\subsection{Redox reactions between NADH in $\mathrm{W}$ and quinone derivatives in $\mathrm{O}^{26}$}

The oxidation of reduced $\beta$-nicotinamide adenine dinucleotide, $\mathrm{NADH}$, by quinone derivative is the essential reaction in the proton transport and the energy accumulation occurring at the mitochondrial inner membrane. The famous model for the oxidation of NADH coupled with the proton transport is "Q cycle"27 as follows; $\mathrm{NADH}$ in the aqueous solution (matrix) is oxidized to $\mathrm{NAD}^{+}$by $\mathrm{Q}$ in the membrane producing hydroquinone, $\mathrm{QH}_{2}$, with the aid of dehydrogenase complex which contains flavin mononucleotide and iron-sulfur center, and the $\mathrm{QH}_{2}$ diffused to cytochrome $\mathrm{bc}_{1}$ complex is oxidized to $\mathrm{Q}$ via semiquinone radical, $\mathrm{Q}^{-}$, which complexes with proton. During these processes, proton is transported from the matrix to the intermembrane space.

Oxidation processes of NADH by $\mathrm{Q}$ in an aqueous solution or non-aqueous solutions were proposed based on static and kinetic studies to be simultaneous transfers of 2 electrons and 1 proton ${ }^{28}$ or successive transfers of 1 electron -1 proton -1 electron. ${ }^{29}$ However, it is difficult to connect the processes in homogeneous solutions to heterogeneous reactions occurring at the aqueous/membrane interface.

The present authors investigated the redox process between $\mathrm{NADH}$ in W and 2,3,5,6-tetrachloro-1,4-benzoquinone, CQ, in DCE as the function of $E$ applied at the W/DCE interface. ${ }^{26}$

Curve 1 in Fig. 2 is the polarogram for charge transfer at the interface between $\mathrm{W}$ of $\mathrm{pH}=7$ containing $5 \times 10^{-3} \mathrm{M} \mathrm{NADH}$ and $1 \mathrm{M} \mathrm{Li}_{2} \mathrm{SO}_{4}$ (SE) and DCE containing $10^{-2} \mathrm{M} \mathrm{CQ}$ and $0.05 \mathrm{M}$ $\mathrm{TPenA}^{+} \mathrm{TFPB}^{-}$(SE). Taking into account the products in $\mathrm{W}$ and DCE obtained by CPDE carried out by applying $E$ available for the limiting current in curve 1, the reaction in the range of $E$ where the negative current wave appeared (defined as Range A) was estimated to be composed of 2-electron oxidation of NADH and 1-electron reduction of CQ at the $\mathrm{W} / \mathrm{DCE}$ interface. The oxidation of NADH is accompanied by the dissociation of $1 \mathrm{H}^{+}$in $\mathrm{W}$.

$$
\mathrm{NADH}_{\mathrm{W}}+2 \mathrm{CQ}_{\mathrm{DCE}} \rightarrow \mathrm{NAD}^{+}{ }_{\mathrm{W}}+\mathrm{H}^{+}{ }_{\mathrm{W}}+2 \mathrm{CQ}^{\cdot-}{ }_{\mathrm{DCE}}
$$

It was confirmed by CPDE carried out by applying $E$ in the range where the current was negligible in curve 1 (defined as Range B) that the reaction between NADH and CQ proceeded even at $E$ in 


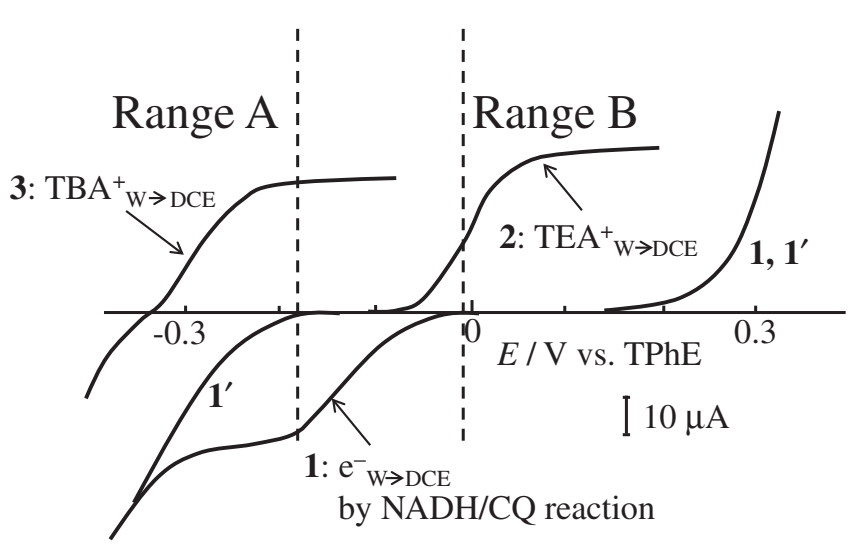

Figure 2. Polarograms for electron transfer due to the oxidation of $\mathrm{NADH}$ in $\mathrm{W}$ by $\mathrm{CQ}$ in DCE (curve 1) and ion transfer at the $\mathrm{W} / \mathrm{DCE}$ interface (curve 2 or 3). Curve 1: $5 \times 10^{-3} \mathrm{M}$ NADH in W and $10^{-2} \mathrm{M} \mathrm{CQ}$ in DCE. Curve $2: 2 \times 10^{-4} \mathrm{M} \mathrm{TEA}^{+}$in W. Curve 3: $2 \times 10^{-4} \mathrm{M} \mathrm{TBA}^{+}$in W. Curve $1^{\prime}$; Residual current for curve 1 .

Range B. The reaction was estimated to be that of Eq. (26) based on the products in $\mathrm{W}$ and DCE after the CPDE.

$$
\mathrm{NADH}_{\mathrm{W}}+\mathrm{H}^{+}{ }_{\mathrm{W}}+\mathrm{CQ}_{\mathrm{DCE}} \rightarrow \mathrm{NAD}^{+}{ }_{\mathrm{W}}+\mathrm{CQH}_{2, \mathrm{DCE}}
$$

In this reaction, currents are cancelled out due to the simultaneous transfers of 2 negative $\left(2 \mathrm{e}^{-}\right)$and positive charges $\left(2 \mathrm{H}^{+}\right)$at the W/ DCE interface.

It was also demonstrated that the interfacial redox reaction between NADH and CQ could be controlled by selecting an ion transfer reaction occurring simultaneously with the redox reaction at the W/DCE interface. In this investigation, $\mathrm{W}$ of $\mathrm{pH}=7$ containing $10^{-3} \mathrm{M}$ NADH and $2 \times 10^{-3} \mathrm{M}$ tetraalkylammonium ion, $\mathrm{R}_{4} \mathrm{~N}^{+}$was shaken for $1 \mathrm{~h}$ under the deaerated condition with the same volume of DCE containing $10^{-3} \mathrm{M} C Q$. When $\mathrm{R}_{4} \mathrm{~N}^{+}$in $\mathrm{W}$ was $\mathrm{TEA}^{+}$, the transfer of $\mathrm{TEA}^{+}$was not observed, and almost all of NADH was oxidized to $\mathrm{NAD}^{+}$and almost all of $\mathrm{CQ}$ was reduced to $\mathrm{CQH}_{2}$. The identical result was obtained in the absence of $\mathrm{R}_{4} \mathrm{~N}^{+}$. When $\mathrm{R}_{4} \mathrm{~N}^{+}$ was tetrabutylammonium ion, $\mathrm{TBA}^{+}$, a half amount of $\mathrm{TBA}^{+}$was transferred to DCE, and a half amount of $\mathrm{NADH}$ was oxidized to $\mathrm{NAD}^{+}$and almost all of CQ was reduced to $\mathrm{CQ}^{-}{ }^{-}$. Here, the halfwave potential in the voltammogram for the transfer of $\mathrm{TEA}^{+}$or $\mathrm{TBA}^{+}$from $\mathrm{W}$ to DCE was observed in Range $\mathbf{B}$ or Range $\mathbf{A}$, respectively, as shown in Fig. 2.

The result introduced here demonstrated that two kinds of redox reactions occur between NADH in W and CQ in DCE depending on $E$, and the reaction can be controlled by selecting the ion transfer reaction occurring at the $\mathrm{W} / \mathrm{DCE}$ interface.

\subsection{Redox reactions between $\mathrm{O}_{2}$ and a hydroquinone at the W/O interface ${ }^{30}$}

The reduction of $\mathrm{O}_{2}$ by organic substances is fairly slow in aqueous or non-aqueous solutions in spite of the high redox potential of $\mathrm{O}_{2}$. However, $\mathrm{O}_{2}$ is utilized effectively as the terminal oxidant in the respiratory chain in bio-systems with redox enzymes. ${ }^{31,32}$ The final reduction products of $\mathrm{O}_{2}$ in $\mathrm{W}$ are $\mathrm{H}_{2} \mathrm{O}_{2}$ and $\mathrm{H}_{2} \mathrm{O}$ in the respiratory chain, and the control of $\mathrm{H}_{2} \mathrm{O}_{2}$ production is very important in physiological phenomena since $\mathrm{H}_{2} \mathrm{O}_{2}$ works as a toxic substance causing the destruction of the cell or organic compounds essential to the living body on one hand, and works as a useful substance to decompose compounds harmful for the living body on the other hand. ${ }^{33}$

The reduction of $\mathrm{O}_{2}$ proceeds accompanying the transfer of an ion such as proton through a biomembrane, ${ }^{34}$ and the reaction rate or even the process is considered to vary depending on the kind of the transferring ion. (a)

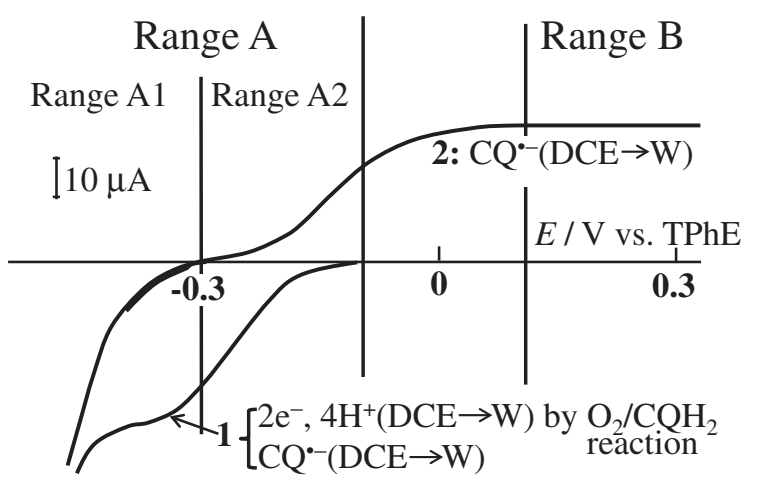

(b)

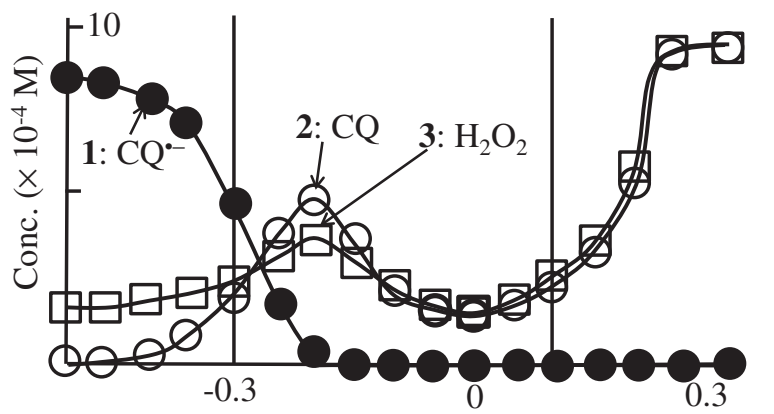

$E / \mathrm{V}$ vs. TPhE

Figure 3. (a) Polarograms observed at the W/DCE interface. Curve 1: reduction of $\mathrm{O}_{2}$ (saturated with air) in $\mathrm{W}$ by $10^{-3} \mathrm{M} \mathrm{CQH}_{2}$ in DCE. Curve 2: transfer of $\mathrm{CQ}^{--}$from DCE containing $10^{-3} \mathrm{M}$ $\mathrm{CQ}^{--}$to W. (b) Concentrations of $\mathrm{CQ}^{--}$(curve 1), CQ (curve 2) and $\mathrm{H}_{2} \mathrm{O}_{2}$ (curve 3) produced after CPDE for $4 \mathrm{~h}$ at $E$ applied between W containing $\mathrm{O}_{2}$ (saturated with air) and DCE containing $10^{-3} \mathrm{MCQH}_{2}$.

In this section, the redox reaction between $\mathrm{O}_{2}$ in $\mathrm{W}$ and $\mathrm{QH}_{2}$ in DCE and the ion transfer at the W/DCE interface accompanied by the redox reaction ${ }^{30}$ are introduced. Here, tetrachlorohydroquinone, $\mathrm{CQH}_{2}$, of which structure is simple and the chemical property was well studied was adopted as the $\mathrm{QH}_{2}$.

Curve 1 in Fig. 3 is the charge transfer polarogram observed at the interface between $\mathrm{W}$ of $\mathrm{pH}=7.0$ containing $\mathrm{O}_{2}$ (saturated with air) and $0.5 \mathrm{M} \mathrm{Li}_{2} \mathrm{SO}_{4}$ (SE) and DCE containing $10^{-3} \mathrm{M} \mathrm{CQH}_{2}$ and $0.05 \mathrm{M}$ TPenA $^{+} \mathrm{TFPB}^{-}$(SE).

When CPDE was carried out by applying $E$ more negative than $-0.3 \mathrm{~V}$ versus $\mathrm{TPhE}$ (defined as Range A1) where the negative current wave was observed in curve 1 , the dominant species produced in DCE was tetrachloroquinone anion radical, $\mathrm{CQ}^{-}$. When $E$ applied was between -0.3 and $-0.1 \mathrm{~V}$ (defined as Range A2), the dominant product in DCE was CQ. The almost quantitative oxidation of $\mathrm{CQH}_{2}$ to $\mathrm{CQ}$ was observed even when CPDE was carried out by applying $E$ more positive than $0.1 \mathrm{~V}$ (defined as Range $\mathrm{B}$ ) where the current in curve 1 was negligible.

The concentration of $\mathrm{H}_{2} \mathrm{O}_{2}$ produced in $\mathrm{W},\left[\mathrm{H}_{2} \mathrm{O}_{2}\right]_{W}$, by the $\mathrm{CPDE}$ was compared with those of $\left.\mathrm{CQ}^{\cdot-}, \mathrm{CQ}^{--}\right]_{\mathrm{DCE}}$, and $\mathrm{CQ}$, $[\mathrm{CQ}]_{\mathrm{DCE}}$, produced in DCE taking into account the stoichiometry of the reaction between $\mathrm{O}_{2}$ and $\mathrm{CQH}_{2}$, and assuming the final reduction product of $\mathrm{O}_{2}$ as $\mathrm{H}_{2} \mathrm{O}_{2}$ (i.e., $\left[\mathrm{H}_{2} \mathrm{O}_{2}\right]_{\mathrm{W}} /\left[\mathrm{CQ}^{--}\right]_{\mathrm{DCE}}=1 / 2$ when the product is $\mathrm{CQ}^{--}$and $\left[\mathrm{H}_{2} \mathrm{O}_{2}\right]_{\mathrm{W}} /[\mathrm{CQ}]_{\mathrm{DCE}}=1$ when the product is $\mathrm{CQ})$. The $\left[\mathrm{H}_{2} \mathrm{O}_{2}\right]_{\mathrm{W}}$ produced at $E$ in Range $\mathrm{A} 1$ or A2 was less than that calculated by using $\left[\mathrm{CQ}^{--}\right]_{\mathrm{DCE}}$ or $[\mathrm{CQ}]_{\mathrm{DCE}}$, respectively, indicating the further reduction of $\mathrm{H}_{2} \mathrm{O}_{2}$ to $\mathrm{H}_{2} \mathrm{O}$. On the other hand, $\left[\mathrm{H}_{2} \mathrm{O}_{2}\right]_{\mathrm{W}}$ produced at $E$ in Range $\mathrm{B}$ was identical with that calculated by using $[\mathrm{CQ}]_{\mathrm{DCE}}$.

The possibility of the reduction of $\mathrm{H}_{2} \mathrm{O}_{2}$ to $\mathrm{H}_{2} \mathrm{O}$ in $\mathrm{W}$ by $\mathrm{CQH}_{2}$ in DCE was also examined by the CPDE carried out by using $\mathrm{W}$ containing $10^{-3} \mathrm{M} \mathrm{H}_{2} \mathrm{O}_{2}$ instead of $\mathrm{O}_{2}$, and it was confirmed that the reduction of $\mathrm{H}_{2} \mathrm{O}_{2}$ proceeded when $E$ in Range $\mathrm{A} 1$ or $\mathrm{A} 2$ was applied, but the reduction was negligible when $E$ in Range $\mathrm{B}$ was 
applied. In this connection, the interfacial redox reaction was confirmed to be much slower than that controlled by the diffusion of $\mathrm{H}_{2} \mathrm{O}_{2}$ or $\mathrm{CQH}_{2}$ based on the polarographic measurement.

The redox processes were estimated as follows based on the results described above.

Process occurring at $E$ in Range A1

$$
\mathrm{O}_{2, \mathrm{~W}}+2 \mathrm{CQH}_{2, \mathrm{DCE}} \rightarrow \mathrm{H}_{2} \mathrm{O}_{2, \mathrm{~W}}+2 \mathrm{H}^{+}{ }_{\mathrm{W}}+2 \mathrm{CQ}^{-{ }^{-}} \text {DCE }
$$

In this reaction, 2 electrons and $4 \mathrm{H}^{+}$liberated from $2 \mathrm{CQH}_{2}$ move from DCE to W. Consequently, 2 positive charges transfer from DCE to $\mathrm{W}$ across the interface as the balance, which causes the negative current wave in curve 1 in Fig. 3. The $\mathrm{H}_{2} \mathrm{O}_{2}$ generated in $\mathrm{W}$ also reacted with $\mathrm{CQH}_{2}$ producing $\mathrm{H}_{2} \mathrm{O}$ when $E$ was Range A1 or A2.

$$
\mathrm{H}_{2} \mathrm{O}_{2, \mathrm{~W}}+2 \mathrm{CQH}_{2, \mathrm{DCE}} \rightarrow 2 \mathrm{H}_{2} \mathrm{O}_{\mathrm{W}}+2 \mathrm{H}^{+}{ }_{\mathrm{W}}+2 \mathrm{CQ}^{-{ }^{-}} \text {DCE }
$$

Process occurring at $E$ in Range A2

In addition to reactions of Eqs. (27) and (28) observed in Range $\mathrm{A}$, the product in $\mathrm{DCE}\left(\mathrm{CQ}^{\circ}\right)$ transfers to $\mathrm{W}$ at $E$ in Range A2 (curve 2 in Fig. 3) since $\mathrm{CQ}^{\circ-}$ has a charge.

$$
\mathrm{CQ}^{\cdot-}{ }^{\mathrm{DCE}} \rightarrow \mathrm{CQ}^{--} \mathrm{W}
$$

The $\mathrm{CQ}^{-}$transferred protonates producing $\mathrm{H}^{+} \mathrm{CQ}^{\bullet-}$. $\mathrm{H}^{+} \mathrm{CQ}^{\bullet-}$ disproportionates and forms $\mathrm{CQ}$ and $\mathrm{CQH}_{2}$ which transfer easily to DCE since they are neutral and hydrophobic.

$$
\begin{aligned}
& \mathrm{CQ}^{\cdot-}{ }_{\mathrm{w}}+\mathrm{H}^{+}{ }_{\mathrm{w}} \rightarrow \mathrm{H}^{+} \mathrm{CQ}^{\cdot-} \mathrm{w} \\
& 2 \mathrm{H}^{+} \mathrm{CQ}^{\cdot-}{ }_{\mathrm{W}} \rightarrow \mathrm{CQ}_{\mathrm{W}}+\mathrm{CQH}_{2, \mathrm{~W}}
\end{aligned}
$$

Process occurring at $E$ in Range $\mathrm{B}$

The further reduction of $\mathrm{H}_{2} \mathrm{O}_{2}$ to $\mathrm{H}_{2} \mathrm{O}$ by Eq. (28) does not proceed in Range $\mathrm{B}$. The overall reaction at $E$ in this range can be described as Eq. (32).

$$
\mathrm{O}_{2, \mathrm{~W}}+\mathrm{CQH}_{2, \mathrm{DCE}} \rightarrow \mathrm{H}_{2} \mathrm{O}_{2, \mathrm{~W}}+\mathrm{CQ}_{\mathrm{DCE}}
$$

In this reaction, since 2 positive charges $\left(2 \mathrm{H}^{+}\right)$and 2 negative charges $\left(2 \mathrm{e}^{-}\right)$transfer across the W/DCE interface, the current at the interface becomes zero as the net.

In Ref. 30, the reduction of $\mathrm{O}_{2}$ in $\mathrm{W}$ by $\mathrm{CQH}_{2}$ in DCE with the aid of ion transfer at the interface was also discussed though it is omitted here.

\subsection{Selective ion transfer accompanied by a respiration mimetic reaction at the W/O interface ${ }^{35}$}

It is well known that the selective transport of ions through a mitochondrial inner membrane is attained when the oxygen supplied by the respiration oxidizes glycolysis products in mitochondria. The energy which enables the ion transport has been attributed to that supplied by electron transport through the membrane due to a redox reaction occurring at the $\mathrm{W} /$ membrane interface accompanied by respiration. ${ }^{34}$

In this section, an example of selective ion transfers accompanied by a respiration mimetic reaction at the $\mathrm{W} / \mathrm{NB}$ interface realized by present authors ${ }^{35}$ is introduced.

When the W/NB system as Eq. (33) had been stood for $5 \mathrm{~h}$ with bubbling $\mathrm{O}_{2}$ into $\mathrm{W}$, the spontaneous transfer of $1.92 \times 10^{-5}$ moles of $\mathrm{Na}^{+}$from NB to $\mathrm{W}$, the evolution of $9.8 \times 10^{-6}$ moles of $\mathrm{CO}_{2}$ in $\mathrm{W}$ and the decrease of $9.4 \times 10^{-6}$ moles of pyruvic acid in $\mathrm{W}$ were found. The transfer of $\mathrm{K}^{+}$was negligible as less than $10^{-7}$ moles.

$$
\begin{array}{l|l}
2.5 \times 10^{-4} \mathrm{M} \mathrm{FMN}, & 0.01 \mathrm{M} \mathrm{DMFC}, \\
1.0 \times 10^{-3} \mathrm{M} \text { pyruvic acid, } & 1.0 \times 10^{-3} \mathrm{M} \mathrm{Na}^{+} \mathrm{TFPB}^{-}, \\
\mathrm{pH} \text { buffer }\left(1.6 \times 10^{-2} \mathrm{M} \mathrm{Li}_{2} \mathrm{HPO}_{4}+\right. & 1.0 \times 10^{-3} \mathrm{M} \mathrm{K}^{+} \mathrm{TFPB}^{-}, \\
\left.4 \times 10^{-3} \mathrm{M} \mathrm{LiH}_{2} \mathrm{PO}_{4} ; \mathrm{pH}=7.0\right) & 4.0 \times 10^{-3} \mathrm{M} \text { valinomycin }^{(W: 20 \mathrm{~mL})} \\
(\mathrm{NB}: 20 \mathrm{~mL})
\end{array}
$$

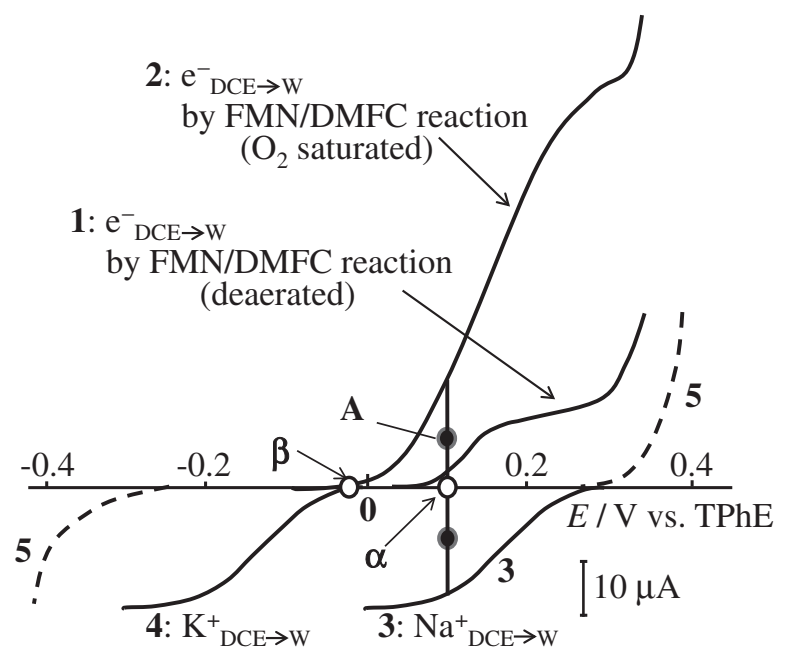

Figure 4. Polarograms for electron and ion transfers at the $\mathrm{W} / \mathrm{NB}$ interface. Curve 1: electron transfer between $\mathrm{W}$ containing $2.5 \times$ $10^{-4} \mathrm{M}$ FMN and NB containing 0.01 M DMFC observed under deaerated condition. Curve 2: as curve 1, but saturated with $\mathrm{O}_{2}$. Curve 3 or 4 : transfer of $\mathrm{Na}^{+}$or $\mathrm{K}^{+}$from NB containing $5 \times 10^{-4} \mathrm{M}$ $\mathrm{Na}^{+} \mathrm{TFPB}^{-}$or $\mathrm{K}^{+} \mathrm{TFPB}^{-}$and $4 \times 10^{-3} \mathrm{M}$ valinomycin to $\mathrm{W}$. Curve 5: Residual current.

where FMN and DMFC denote flavin mononucleotide and bis(1,2,3,4,5-pentamethyl-cyclopentadienyl)iron (so-called decamethylferrocene), respectively.

Reaction processes of the spontaneous $\mathrm{CO}_{2}$ evolution coupled with the selective ion transfer described above were elucidated as follows;

Curve 1 in Fig. 4 is the polarogram observed under deaerated condition at the interface between $\mathrm{W}$ of $\mathrm{pH}=7.0$ containing $2.5 \times 10^{-4} \mathrm{M}$ FMN and $0.1 \mathrm{M} \mathrm{Li}_{2} \mathrm{SO}_{4}$ (SE) and NB containing $0.01 \mathrm{M}$ DMFC and $0.05 \mathrm{M} \mathrm{TPenA}^{+} \mathrm{TFPB}^{-}$(SE). Taking into account the products after CPDE, the positive current wave was estimated to be caused by one electron transfer due to the interfacial redox reaction as Eq. (34).

$$
\mathrm{FMN}_{\mathrm{W}}+\mathrm{DMFC}_{\mathrm{NB}}+\mathrm{H}^{+}{ }_{\mathrm{W}} \rightarrow \mathrm{FMNH}_{\mathrm{W}}{ }+\mathrm{DMFC}^{+} \mathrm{NB}
$$

The polarogram shown as curve 2 in Fig. 4 was recorded under the same condition as that for curve 1 , but bubbling $\mathrm{O}_{2}$ into $\mathrm{W}$. Although the potential range for the positive current wave in curve 2 was identical with that in curve 1 , the limiting current in curve 2 was about 6 times larger than that in curve 1 . The large current can be explained by considering the reduction of $\mathrm{O}_{2}$ catalyzed by the FMN/FMNH' redox reaction as Eq. (34). In the catalytic reaction, the reduction product $\left(\mathrm{FMNH}^{\circ}\right)$ was oxidized by $\mathrm{O}_{2}$ regenerating FMN that can be reduced again through the reaction of Eq. (34).

$$
2 \mathrm{FMNH}_{\mathrm{W}}{ }_{\mathrm{W}}+\mathrm{O}_{2, \mathrm{~W}} \rightarrow 2 \mathrm{FMN}_{\mathrm{W}}+\mathrm{H}_{2} \mathrm{O}_{2, \mathrm{~W}}
$$

Curves 3 and 4 in Fig. 4 are polarograms for transfers of $\mathrm{Na}^{+}$and $\mathrm{K}^{+}$, respectively, from $\mathrm{NB}$ to $\mathrm{W}$ in the presence of valinomycin in NB.

The selective transfer of $\mathrm{Na}^{+}$from $\mathrm{NB}$ to $\mathrm{W}$ in the cell system of Eq. (33) can be understood by referring to the electron transfer and ion transfer polarograms in Fig. 4.

When simultaneous transfers of electrons and cations occur spontaneously at one $\mathrm{W} / \mathrm{NB}$ interface, the positive current due to the transfer of electrons (which carry negative charges) from NB to $\mathrm{W}$ should be equal to the negative current due to the transfer of cations (which carry positive charges) from $\mathrm{NB}$ to $\mathrm{W}$ in order to maintain the electroneutrality in both $\mathrm{W}$ and NB phases. Applying this condition to the present case, the $E$ established by the coupling 
of transfers of electron and $\mathrm{Na}^{+}$at the W/NB interface is expected to be $\alpha$ in Fig. 4. The current $\mathbf{A}$ is significantly large indicating that the transfer of $\mathrm{Na}^{+}$and the reaction of Eq. (34) catalyzed by the reaction of Eq. (35) proceed spontaneously in the system of Eq. (33). Here, the oxidation of pyruvic acid by $\mathrm{H}_{2} \mathrm{O}_{2}$ [the product of the reaction of Eq. (35)] in W producing $\mathrm{CO}_{2}$ is well-known as the oxidative decarboxidation of $\alpha$-keto acids. ${ }^{36}$

$$
\mathrm{CH}_{3}(\mathrm{CO}) \mathrm{COOH}+\mathrm{H}_{2} \mathrm{O}_{2} \rightarrow \mathrm{CH}_{3} \mathrm{COOH}+\mathrm{CO}_{2}+\mathrm{H}_{2} \mathrm{O}
$$

When the cation is $\mathrm{K}^{+}$instead of $\mathrm{Na}^{+}$, the $E$ established by the coupling of transfers of electron and $\mathrm{K}^{+}$is expected to be $\boldsymbol{\beta}$. The potential $\beta$ is more negative than $\alpha$, and the magnitude of the current at $\beta$ is much smaller than that at $\alpha$.

\section{Biomimetic Charge Transfer Reactions Observed by Artificial Membrane Systems}

The membrane potential, $E_{\mathrm{W} 1-\mathrm{W} 2}$, which determines the membrane transport of a charge (ion or electron) from one aqueous solution, W1, to another, W2, through a membrane, $\mathrm{M}$, is composed of potentials due to transfers of the charge at the W1/M and M/W2 interfaces, $E_{\mathrm{W} 1 / \mathrm{M}}$ and $E_{\mathrm{M} / \mathrm{W} 2}$, and those due to mass transfers within $\mathrm{W} 1, \mathrm{M}$ and $\mathrm{W} 2$ phases. It has been widely supposed that the potential for the mass transfer in $\mathrm{M}$ contributes significantly to the membrane potential, since most investigations on the membrane transport employed membranes of high electrical resistances containing negligible concentrations of electrolytes. However, the membrane transport in the presence of rather concentrated electrolytes in the membrane is also important, especially in connection with charge transfers at biomembranes or bilayer lipid membranes, BLMs, which concentrate hydrophobic ions spontaneously into their lipid phases, and even hydrophilic ions when the membranes contain hydrophobic complexing agents. ${ }^{37}$ In this case, the share of the potentials for interfacial charge transfers in the membrane potential is considered to be more significant than that for mass transfers in the membrane.

In this chapter, the method proposed by the present authors for the elucidation of the charge transport process through an LM in the presence of sufficient electrolytes ${ }^{38}$ is introduced, and a few membrane phenomena of which mechanisms were elucidated by the method are introduced.

\subsection{Voltammetric elucidation of the charge transfer process} through an LM in the presence of sufficient electrolytes ${ }^{38}$

The membrane system of Eq. (37) is an example used in the investigation of the membrane transport process. In the cell, W1 and $\mathrm{W} 2(5 \mathrm{~mL}$ each) were separated by $\mathrm{NB}(0.8 \mathrm{~mL})$ which worked as the LM of thickness of $1 \mathrm{~cm}$. Dibenzo-18-crown- 6 was added in the LM to facilitate the transfer of $\mathrm{K}^{+}$from $\mathrm{W} 1$ to $\mathrm{LM}$. RE1 and RE2 or CE1 and CE2 were reference electrodes or counter electrodes in W1 and W2, respectively. RE3 and RE4 were reference electrodes in LM placed near to the W1/LM and LM/W2 interfaces, respectively.

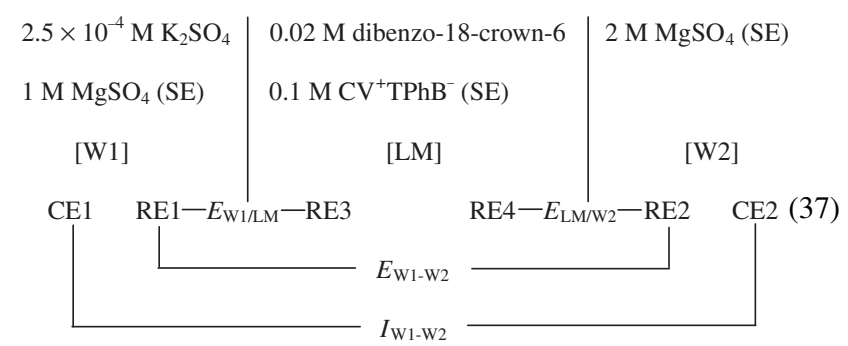

The voltammogram for the charge transfer through a membrane, VCTTM, shown as curve 1 in Fig. 5 was recorded with the cell of Eq. (37) by scanning $E_{\mathrm{W} 1-\mathrm{W} 2}$ applied as the potential of RE1 versus

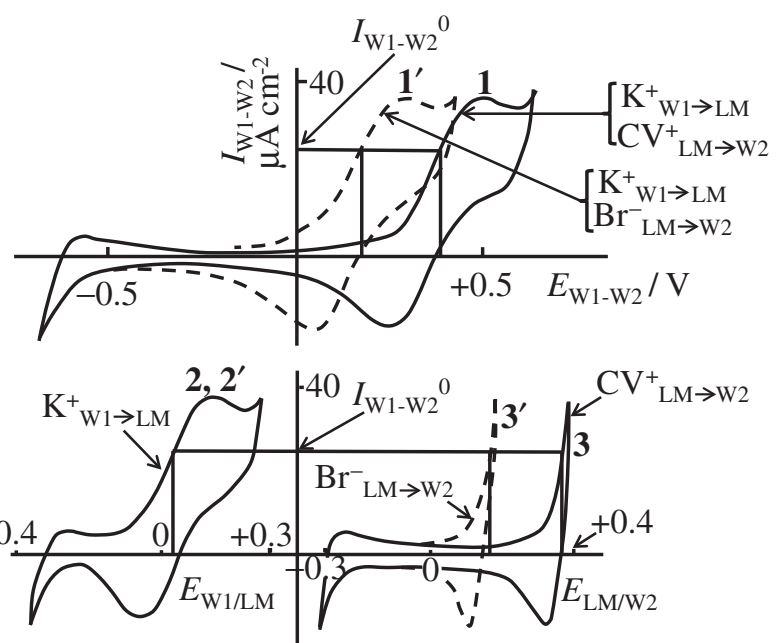

Figure 5. Voltammograms for the ion transfer from $\mathrm{W} 1$ to $\mathrm{W} 2$ through LM (curves 1 and $1^{\prime}$ ), at the W1/LM interface (curves 2 and $2^{\prime}$ ) and at the LM/W2 interface (curves 3 and $3^{\prime}$ ). Compositions: $2.5 \times 10^{-4} \mathrm{M} \mathrm{K}_{2} \mathrm{SO}_{4}+1 \mathrm{M} \mathrm{MgSO}_{4}$ (SE) in $\mathrm{W} 1 ; 0.02 \mathrm{M}$ dibenzo-18-crown-6 $+0.1 \mathrm{M} \mathrm{CV}^{+} \mathrm{TPhB}^{-}$(SE) in $\mathrm{LM} ; 2 \mathrm{M} \mathrm{MgSO}_{4}$ (SE) in $\mathrm{W} 2$ in the absence (curves 1 and 3 ) or in the presence of $0.01 \mathrm{M} \mathrm{MgBr}_{2}$ (curves $1^{\prime}$ and $3^{\prime}$ ).

RE2, and measuring the current between W1 and W2 (i.e., membrane current), $I_{\mathrm{W} 1-\mathrm{W} 2}$. During the recording of the VCTTM, variations of $E_{\mathrm{W} 1 / \mathrm{LM}}$ and $E_{\mathrm{LM} / \mathrm{W} 2}$ were monitored as the function of $I_{\mathrm{W} 1-\mathrm{W} 2}$, and voltammograms at the W1/LM and LM/W2 interfaces were obtained as shown as curves 2 and 3, respectively.

Comparing curve 1 with curves 2 and 3 , it is obvious that (1) the potential window in curve 1 is about twice that in curve 2 or 3 , (2) the potential regions where the positive and the negative peaks appear in curve 1 are different from those in curve 2 , and (3) the slopes of the positive peak, negative peak, final rise and final descent in curve 1 are much smaller than those in curves 2 and 3 .

In order to elucidate the reactions which realize curve 1 , the relation lying among $E_{\mathrm{W} 1-\mathrm{W} 2}$ in curve $1, E_{\mathrm{W} 1 / \mathrm{LM}}$ in curve 2 and $E_{\mathrm{LM} / \mathrm{W} 2}$ in curve 3 was investigated at a definite $I_{\mathrm{W} 1-\mathrm{W} 2}, I_{\mathrm{W} 1-\mathrm{W} 2}{ }^{0}$, taking into account that currents flowing across both the W1/LM and LM/W2 interfaces must be the same and equal to $I_{\mathrm{W} 1-\mathrm{W} 2}{ }^{0}$. The relation as Eq. (38) was found to hold at any $I_{\mathrm{W} 1-\mathrm{W} 2}{ }^{0}$.

$$
E_{\mathrm{W} 1-\mathrm{W} 2}=E_{\mathrm{W} 1 / \mathrm{LM}}+E_{\mathrm{LM} / \mathrm{W} 2}+I_{\mathrm{W} 1-\mathrm{W} 2}{ }^{0} R
$$

where $R$ is the resistance between RE1 and RE2.

When W1, W2 and LM contain sufficient concentrations of electrolytes like the system of Eq. (37), the contribution of $I_{\mathrm{W} 1-\mathrm{W} 2}{ }^{0} R$ to $E_{\mathrm{W} 1-\mathrm{W} 2}$ is not significant, and Eq. (38) can be approximated by Eq. (39).

$$
E_{\mathrm{W} 1-\mathrm{W} 2}=E_{\mathrm{W} 1 / \mathrm{LM}}+E_{\mathrm{LM} / \mathrm{W} 2}
$$

This equation suggests that the membrane potential in the presence of sufficient electrolyte is primarily determined by the potential differences at two interfaces which depend on charge transfer reactions at the interfaces, though the potential differences at interfaces are not apparently taken into account in theoretical equations such as Plank, Henderson and Goldman-Hodgkin-Katz equations which have often adopted in the discussion of the membrane potential.

In Refs. 38 and 39, transports of charges (ion and electron) through BLMs were discussed taking into account the similarity of the voltammograms for transports of charges through BLMs with those through LMs. 


\subsection{Influence of the ion transfer reaction at one W/LM interface on that at another W/LM interface under an applied membrane current ${ }^{38}$}

Voltammograms shown as curves $1^{\prime}, 2^{\prime}$ and $3^{\prime}$ in Fig. 5 were recorded under the same conditions as those for curves 1,2 and 3 in Fig. 5, respectively, but adding $0.01 \mathrm{M} \mathrm{MgBr}_{2}$ into W2. The positive current wave in curve $1^{\prime}$ (VCTTM) appeared at a potential regions about $0.19 \mathrm{~V}$ less positive than that in the absence of $\mathrm{MgBr}_{2}$ in W2 indicating that the transfer of $\mathrm{K}^{+}$from $\mathrm{W} 1$ to $\mathrm{LM}$ in the presence of $0.01 \mathrm{M} \mathrm{MgBr}_{2}$ in $\mathrm{W} 2$ can be achieved even at the membrane potential $0.19 \mathrm{~V}$ less positive than that required for the transfer in the absence of $\mathrm{MgBr}_{2}$. The effect of $\mathrm{MgBr}_{2}$ can be explained by considering that the final rise in the voltammogram at the LM/W2 interface in the presence of $\mathrm{MgBr}_{2}$ in W2 (which is attributable to the transfer of $\mathrm{Br}^{-}$from $\mathrm{W} 2$ to $\mathrm{LM}$ ) lies at a potential about $0.19 \mathrm{~V}$ less positive than that in the absence of $\mathrm{MgBr}_{2}$ (which is attributable to the transfer of $\mathrm{CV}^{+}$from $\mathrm{LM}$ to $\mathrm{W} 2$ ), and hence the positive current wave in the VCTTM (curve $1^{\prime}$ ) composed of the transfer of $\mathrm{K}^{+}$from W1 to LM and that of $\mathrm{Br}^{-}$from W2 to LM appears at a potential about $0.19 \mathrm{~V}$ less positive than that composed of the transfer of $\mathrm{K}^{+}$from $\mathrm{W} 1$ to $\mathrm{LM}$ and that of $\mathrm{CV}^{+}$from $\mathrm{LM}$ to $\mathrm{W} 2$.

\section{Oscillation of Membrane Current Observed with a Liquid Membrane $e^{40,41}$}

The oscillation of membrane current or membrane potential accompanied by an ion transfer through a membrane, which is closely related to the electrical excitability in living organisms, has been investigated extensively by many authors using biomembranes or artificial membranes. ${ }^{42,43}$ Most of the oscillations observed with biomembranes have been attributed to the gating of the "ion channel" composed of transmembrane proteins present in biomembranes, and tremendous efforts have been made to elucidate the gating process, mainly by reconstitution of channel proteins into bilayer membranes. ${ }^{42}$ On the other hand, the oscillations have also been observed with thick LMs as well as artificial BLMs in the absence of any channel proteins, and these oscillations are expected to offer plenty of fundamental information useful in elucidating the oscillation processes at biomembranes in living organisms. ${ }^{40,41}$

In this chapter, the oscillation of membrane current accompanied by the transport of $\mathrm{Na}^{+}$from one aqueous solution, W1, to another, W2, through LM and its mechanism elucidated ${ }^{40,41}$ are introduced. The oscillation has some characteristics similar to those of the oscillation at the biomembrane with so-called "sodium channel", though the membrane system does not contain any channel proteins.

\subsection{Oscillation of membrane current, I $I_{\mathrm{W} 1-\mathrm{W} 2}$, under an applied} membrane potential, $E_{\mathrm{W} 1-\mathrm{W} 2}{ }^{40,41}$

Curve 1 in Fig. 6 is an example of the oscillation of $I_{\mathrm{W} 1-\mathrm{W} 2}$ observed by applying a constant $E_{\mathrm{W} 1-\mathrm{W} 2}$ of $-0.48 \mathrm{~V}$ to the cell system of Eq. (40) composed of W1 $(5 \mathrm{~mL}), \mathrm{W} 2(5 \mathrm{~mL})$ and LM of NB $(0.8 \mathrm{~mL})$. Here, $E_{\mathrm{W} 1-\mathrm{W} 2}$ was applied as the potential of RE2 in $\mathrm{W} 2$ referred to that of RE1 in W1. The oscillation lasted for more than $2 \mathrm{~h}$.

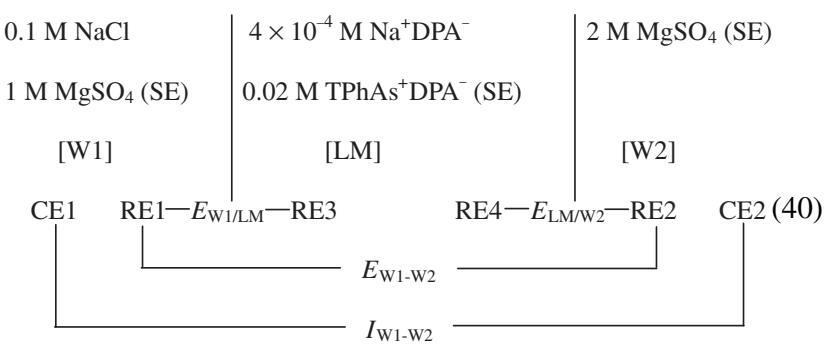

Curves 2 and 3 show time courses of $E_{\mathrm{W} 1 / \mathrm{LM}}$ and $E_{\mathrm{LM} / \mathrm{W} 2}$ observed simultaneously with curve 1 . From these curves, it is

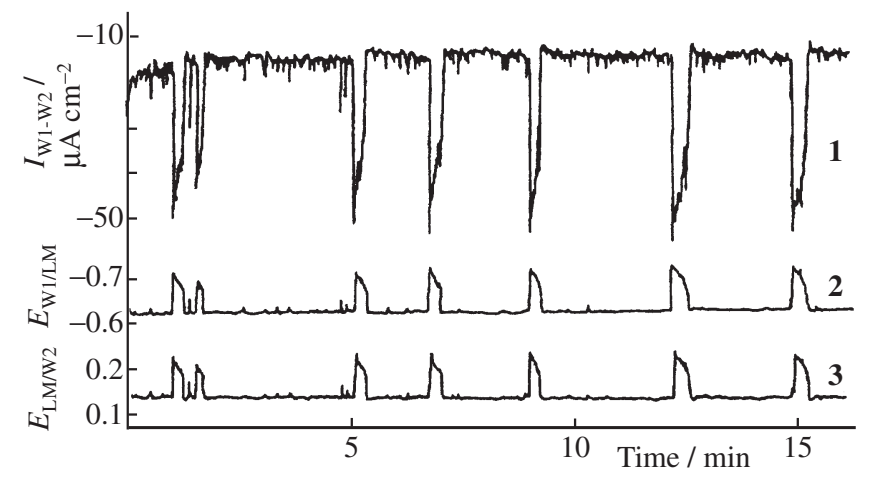

Figure 6. Oscillations of membrane current, $I_{\mathrm{W} 1-\mathrm{W} 2}$, (curve 1) and $E_{\mathrm{W} 1 / \mathrm{LM}}$ (curve 2) or $E_{\mathrm{LM} / \mathrm{W} 2}$ (curve 3) observed by applying a membrane potential, $E_{\mathrm{W} 1-\mathrm{W} 2}$, of $-0.48 \mathrm{~V}$ to the cell of Eq. (40).

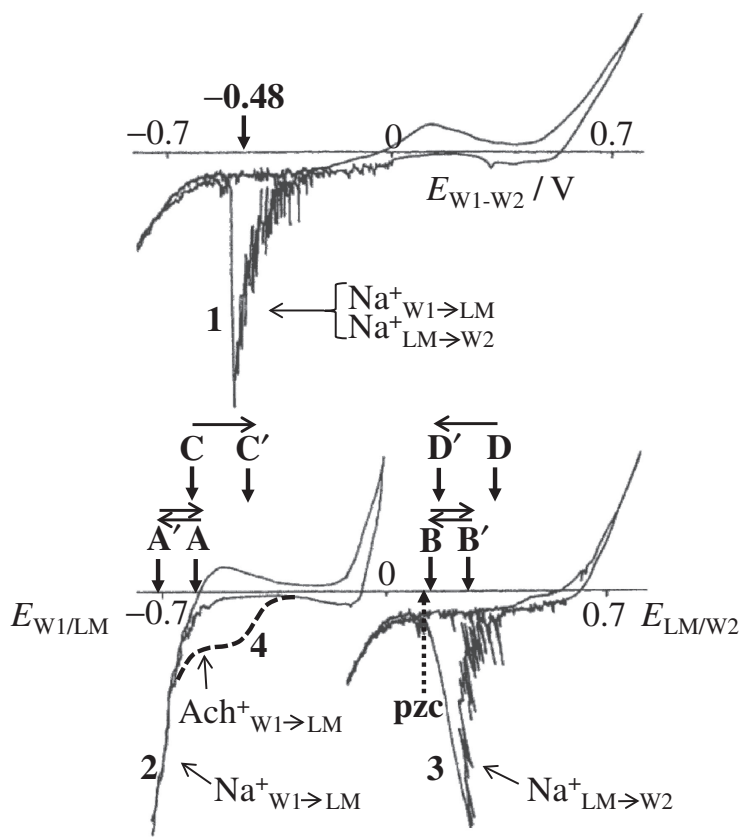

Figure 7. Voltammograms for ion transfers through LM (curve 1), at the W1/LM interface (curve 2) and at the LM/W2 interface (curve 3) recorded with the cell of Eq. (40). Curve 4: transfer of $\mathrm{Ach}^{+}$at the interface of W1 containing $2 \times 10^{-4} \mathrm{M} \mathrm{Ach}^{+}$and LM.

obvious that the current oscillation is accompanied by the oscillations of $E_{\mathrm{W} 1 / \mathrm{LM}}$ and $E_{\mathrm{LM} / \mathrm{W} 2}$. It is notable that the amplitude of the oscillation of $E_{\mathrm{W} 1 / \mathrm{LM}}$ was the same as that of and $E_{\mathrm{LM} / \mathrm{W} 2}$.

\subsection{Mechanism of the oscillation of $I_{\mathrm{W} 1-\mathrm{W} 2}$ under an applied $E_{\mathrm{W} 1-\mathrm{W} 2}$}

The mechanism was discussed referring to voltammograms shown in Fig. 7. Curve 1 is the VCTTM recorded by scanning $E_{\mathrm{W} 1-\mathrm{W} 2}$ and measuring $I_{\mathrm{W} 1-\mathrm{W} 2}$. Curves 2 and 3 are voltammograms at the $\mathrm{W} 1 / \mathrm{LM}$ and $\mathrm{LM} / \mathrm{W} 2$ interfaces, respectively, recorded simultaneously with curve 1 by measuring $E_{\mathrm{W} 1 / \mathrm{LM}}$ and $E_{\mathrm{LM} / \mathrm{W} 2}$ as the function of $I_{\mathrm{W} 1-\mathrm{W} 2}$.

A large current peak appeared in voltammograms 1 and 3. Taking into account Eq. (39), the negative current peak in voltammogram 1 is considered to be composed of the final descent in voltammogram 2 and the peak in voltammogram 3 . Here, the negative peak current in voltammgram 3 was attributed to the maximum due to the transfer of $\mathrm{Na}^{+}$from LM to W2 enhanced by the adsorption of $\mathrm{Na}^{+}$ transferred to $\mathrm{W} 2$ at the LM/W2 interface as an ion pair with 
$\mathrm{DPA}^{-}$in DCE, $\mathrm{Na}^{+} \mathrm{DPA}^{-}$. The final descent in voltammogram 2 was confirmed to be due to the transfer $\mathrm{Na}^{+}$from W1 to LM.

The oscillation of $I_{\mathrm{W} 1-\mathrm{W} 2}$ is brought about by the mutuallydependent ion transfer reactions at the W1/LM and LM/W2 interfaces. When $E_{\mathrm{W} 1-\mathrm{W} 2}$ (i.e., $-0.48 \mathrm{~V}$ ) in the range effective for the maximum current in voltammogram 1 is applied, $E_{\mathrm{W} 1 / \mathrm{LM}}$ and $E_{\mathrm{LM} / \mathrm{W} 2}$ settle at $E$ marked as $\mathbf{A}$ and $\mathbf{B}$, respectively, in Fig. 7, and the relation of Eq. (39) holds among $E_{\mathrm{W} 1-\mathrm{W} 2}, E_{\mathrm{W} 1 / \mathrm{LM}}$ and $E_{\mathrm{LM} / \mathrm{W} 2}$. Here, the magnitude of the current flowing across the W1/LM interface, $I_{\mathrm{W} 1 / \mathrm{LM}}$, at $E_{\mathrm{W} 1 / \mathrm{LM}}$ of $\mathbf{A}$ is the same as that across the LM/W2 interface, $I_{\mathrm{LM} / \mathrm{W} 2}$, at $E_{\mathrm{LM} / \mathrm{W} 2}$ of $\mathbf{B}$ (and equivalent to IW1-W2).

At $E_{\mathrm{LM} / \mathrm{W} 2}$ of $\mathbf{B}, \mathrm{Na}^{+}$transfers from LM to W2, and the $\mathrm{Na}^{+}$ transferred to W2 adsorbs at the LM/W2 interface generating the stirring of the solution in the vicinity of the interface because the absorption induces the change of the interfacial tension at the LM/ W2 interface. Since the stirring enhances the transfer of $\mathrm{Na}^{+}$at the interface, $I_{\mathrm{LM} / \mathrm{W} 2}$ grows up as the maximum current. At the same time, $I_{\mathrm{W} 1 / \mathrm{LM}}$ grows up along the final descent of the voltammogram 2 at the $\mathrm{W} 1 / \mathrm{LM}$ interface, causing the negative shift of $E_{\mathrm{W} 1 / \mathrm{LM}}$ (to $\left.\mathbf{A}^{\prime}\right)$. The negative shift of $E_{\mathrm{W} 1 / \mathrm{LM}}$ results in the positive shift of the $E_{\mathrm{LM} / \mathrm{W} 2}$ (to $\mathbf{B}^{\prime}$ ) because of the relation of Eq. (39). The adsorption at $\mathbf{B}^{\prime}$ is stronger than that at the original $E_{\mathrm{LM} / \mathrm{W} 2}(\mathbf{B})$, since $\mathbf{B}^{\prime}$ is $E$ more remote from the point of zero charge, pzc, of the interface than $\mathbf{B}$. The duration of the adsorption brings about the saturation of the adsorption of $\mathrm{Na}^{+} \mathrm{DPA}^{-}$at the interface and the reduction of the stirring. Because of the reduced stirring and the consumption of $\mathrm{Na}^{+}$ in LM near to the interface owing to the enhanced transfer of $\mathrm{Na}^{+}$, $I_{\mathrm{LM} / \mathrm{W} 2}$ decreases. Simultaneously, $I_{\mathrm{W} 1 / \mathrm{LM}}$ decreases accompanying the positive shift of $E_{\mathrm{W} 1 / \mathrm{LM}}$ to around $\mathbf{A}$ and the negative shift of $E_{\mathrm{LM} / \mathrm{W} 2}$ to around $\mathbf{B}$ [cf., Eq. (39)]. At the $E_{\mathrm{LM} / \mathrm{W} 2}$ around $\mathbf{B}$ where is nearer to pzc than $\mathbf{B}^{\prime}, \mathrm{Na}^{+} \mathrm{DPA}^{-}$which has been adsorbed at the LM/W2 interface desorbs into LM, because the adsorption at this $E_{\mathrm{LM} / \mathrm{W} 2}(\mathbf{B})$ is weaker than that at the positive $E_{\mathrm{LM} / \mathrm{W} 2}\left(\mathbf{B}^{\prime}\right)$, and $\mathrm{Na}^{+} \mathrm{DPA}^{-}$is hydrophobic rather than hydrophilic. The desorption followed by the dissociation of the ion pair restores the activity of $\mathrm{Na}^{+}$in $\mathrm{LM}$ in the vicinity of the interface. Hence, the current increases again, causing the positive shift of $E_{\mathrm{LM} / \mathrm{W} 2}$. These processes repeat to realize the oscillation of the membrane current. In this regard, the shifts of $E_{\mathrm{W} 1 / \mathrm{LM}}$ and $E_{\mathrm{LM} / \mathrm{W} 2}$ accompanied with the current oscillation were clearly observed as curves 2 and 3 in Fig. 6.

\subsection{The induction and inhibition of the oscillation of $I_{\mathrm{W} 1-\mathrm{W} 2}$}

Though the current oscillation was not observed when the applied $E_{\mathrm{W} 1-\mathrm{W} 2}$ was $-0.30 \mathrm{~V}$, it was induced when acetylcholine ion, $\mathrm{Ach}^{+}$, was added into W1, similarly to the induction of the current oscillation at a biomembrane with the "sodium channel". ${ }^{43}$ The induction can be understood with the aid of voltammograms in Fig. 7. Here, curve 4 in Fig. 7 is the schematic voltammogram for the transfer of $\mathrm{Ach}^{+}$from W1 to LM.

When $-0.30 \mathrm{~V}$ is applied as $E_{\mathrm{W} 1-\mathrm{W} 2}$ to the cell, $E_{\mathrm{W} 1 / \mathrm{LM}}$ and $E_{\mathrm{LM} / \mathrm{W} 2}$ settle at $E$ indicated as $\mathbf{C}$ and $\mathbf{D}$, respectively, and satisfy the relation of Eq. (39). The $E$ of $\mathbf{D}$ is not effective for the maximum current, and hence the oscillation does not start. When $\mathrm{Ach}^{+}$is added into $\mathrm{W} 1$ to be e.g., $4 \times 10^{-4} \mathrm{M}, E_{\mathrm{W} 1 / \mathrm{LM}}$ shifts to a less negative $E\left(\mathbf{C}^{\prime}\right)$ because $I_{\mathrm{W} 1 / \mathrm{LM}}$ is undertaken by the transfer of $\mathrm{Ach}^{+}$from W1 to LM (cf., curve 4). At the same time, according to the relation of Eq. (39), $E_{\mathrm{LM} / \mathrm{W} 2}$ shifts to $\mathbf{D}^{\prime}$ less positive than $\mathbf{D}$ and effective for the maximum current due to the transfer and adsorption of $\mathrm{Na}^{+}$. Therefore, the oscillation of $I_{\mathrm{W} 1-\mathrm{W} 2}$ is realized in the presence of $\mathrm{Ach}^{+}$.

The current oscillation observed by applying $E_{\mathrm{W} 1-\mathrm{W} 2}=-0.48 \mathrm{~V}$ was inhibited when a rather hydrophobic ion was added to W1 similarly to the inhibition of the current oscillation at a biomembrane, ${ }^{42,43}$ though the explanation is omitted here.
In Refs. 40 and 41, the oscillation of membrane potential observed under an applied membrane current was also introduced.

\subsection{The adsorption of an ion pair at the W/O interface ${ }^{41}$}

Concerning with the absorption of an ion pair $\left(\mathrm{Na}^{+} \mathrm{DPA}^{-}\right)$at the W2/LM interface which was necessary to realize the oscillation of the membrane current, it should be noted that the chemical nature of $\mathrm{Na}^{+}$just after its transfer from NB (LM) to $\mathrm{W}$ is different from that of $\mathrm{Na}^{+}$in the bulk of $\mathrm{W}$. When the voltammogram for the ion transfer was investigated at the interface between $\mathrm{W}$ containing $10^{-4}$ to $0.01 \mathrm{M} \mathrm{Na}_{2} \mathrm{SO}_{4}$ in addition to $\mathrm{SE}\left(1 \mathrm{M} \mathrm{MgSO}_{4}\right)$ and $\mathrm{NB}$ containing only SE $\left(0.02 \mathrm{M} \mathrm{TPhAs}^{+} \mathrm{DPA}^{-}\right)$in the absence of $\mathrm{Na}^{+}$, the maximum current was not observed, indicating that the adsorption of $\mathrm{Na}^{+}$at the $\mathrm{W} / \mathrm{NB}$ interface as $\mathrm{Na}^{+} \mathrm{DPA}^{-}$did not occur when $\mathrm{Na}^{+}$was added in $\mathrm{W}$ instead of in NB. Though further investigation is necessary, the present authors consider that the $\mathrm{Na}^{+}$ just after the transfer from NB to $\mathrm{W}$ which stays in the vicinity of $\mathrm{W}$ is chemically active and hence form the ion pair $\left(\mathrm{Na}^{+} \mathrm{DPA}^{-}\right)$at the interface because of the reason as follows; A hydrophilic ion in $\mathrm{W}$ is considered to be more stable than that in $\mathrm{O}$, since the solvation with water molecules is stronger than that with organic molecules. When the ion transfers from $\mathrm{O}$ to $\mathrm{W}$, water molecules exchange for organic solvent molecules solvated to the ion, and the partly exchanged state may be realized at the $\mathrm{W} / \mathrm{O}$ interface. The ion of partly exchanged state, which was called as "fresh ion" by the present authors, is chemically more active than that of fully exchanged by water molecules, and hence the "fresh ion" can form the ion pair.

In connection with the "fresh ion", it is considered that not only the ion transfer from $\mathrm{O}$ to $\mathrm{W}$ but also that from the biomembrane to W might generate the "fresh ion" since the biomembrane offers a hydrophobic atmosphere similarly to O.

\section{Membrane Transport in the Presence of an Applied Electrical Potential Gradient Parallel to the Aqueous/ Membrane Interface 44,45}

Generally speaking, the membrane transport of a charge (ion or electron) from one aqueous solution, W1, to another, W2, across a membrane, $\mathrm{M}$, is realized when a potential gradient perpendicular to the $\mathrm{W} 1 / \mathrm{M}$ and $\mathrm{W} 2 / \mathrm{M}$ interfaces is applied between $\mathrm{W} 1$ and $\mathrm{W} 2$. However, it is supposed that the membrane transport might be realized also when a potential gradient parallel to the $\mathrm{W} 1 / \mathrm{M}$ and $\mathrm{W} 2 / \mathrm{M}$ interface is applied between two sites in the aqueous phase or membrane phase. The former and the latter will be called as "perpendicular transport" and "parallel transport", respectively, hereafter. The "parallel transport" is considered to occur at the interface between an aqueous solution and a heterogeneous biomembrane with various domains.

In this section, the fundamental feature of the "parallel transport" realized by applying potential difference between two sites (A and B), $E_{\mathrm{M}(\mathrm{A}-\mathrm{B})}$, in $\mathrm{LM}^{45}$ is introduced as an example.

Figure $8(\mathrm{a})$ is the schematic illustration of the cell used to observe the "parallel transport". The LM was composed of DCE $\left(10 \mathrm{~mL}: 0.7 \mathrm{~cm}\right.$ thick) containing a dilute SE (e.g., $10^{-4} \mathrm{M}$ $\left.\mathrm{TPenA}^{+} \mathrm{TPhB}^{-}\right)$, and $\mathrm{W} 1$ and $\mathrm{W} 2(10 \mathrm{~mL}: 0.7 \mathrm{~cm}$ thick) contained $1 \mathrm{M}$ and $2 \mathrm{M} \mathrm{MgSO}_{4}$, respectively, as SE. Two reference electrodes, $\mathrm{RE}_{\mathrm{A}, \mathrm{M}}$ and $\mathrm{RE}_{\mathrm{B}, \mathrm{M}}$, were set at sites $\mathbf{A}$ and $\mathbf{B}$ in $\mathrm{LM}$, and $E_{\mathrm{M}(\mathrm{A}-\mathrm{B})}$ was applied as the potential of $R E_{A, M}$ versus that of $R E_{B, M}$. The distance between sites $\mathbf{A}$ and $\mathbf{B}$ was $12 \mathrm{~cm}$ (as an example). Two counter electrodes, $\mathrm{CE}_{\mathrm{A}, \mathrm{M}}$ and $\mathrm{CE}_{\mathrm{B}, \mathrm{M}}$, of platinum wires were set at sites $\mathbf{A}$ and $\mathbf{B}$ in LM.

When $E_{\mathrm{M}(\mathrm{A}-\mathrm{B})}$ of $1 \mathrm{~V}$ was applied for $3 \mathrm{~h}$ between sites $\mathbf{A}$ and $\mathbf{B}$ in LM in the cell of Fig. 8(a) of which W1 contained $2 \times 10^{-4} \mathrm{M}$ picrate, $\mathrm{Pic}^{-}$, in addition to $1 \mathrm{M} \mathrm{MgSO}_{4}, \mathrm{Pic}^{-}$transferred from W1 to W2 through a definite region between sites $\mathbf{A}$ and $\mathbf{B}$ (site $\mathbf{C}$ : around $4 \mathrm{~cm}$ from site $\mathbf{A}$ ) as shown in Fig. 8(b). 
(a)

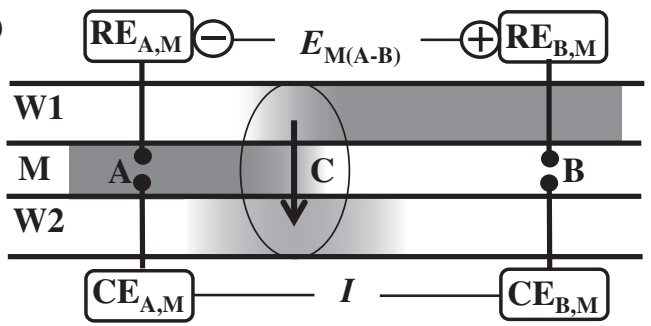

(b)

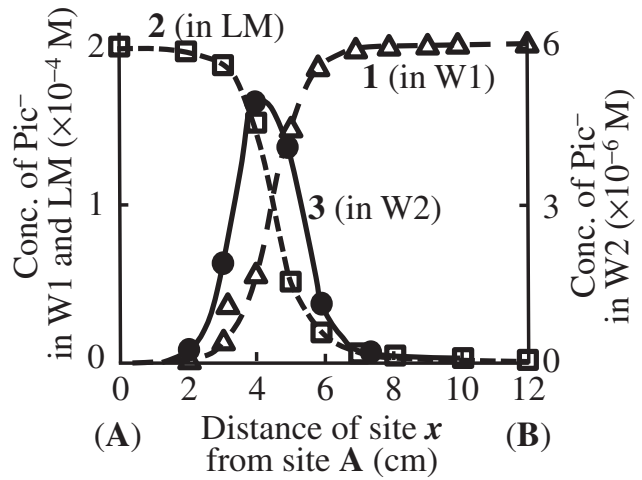

Figure 8. (a) Schematic illustration of the cell for "parallel transport". (b) Relation between the distance of site $\boldsymbol{x}$ from site A and the concentration of $\mathrm{Pic}^{-}$at site $\boldsymbol{x}$ in W1 (curve 1), LM (curve 2) or W2 (curve 3) after electrolysis for $3 \mathrm{~h}$ by applying $1 \mathrm{~V}$ between sites $\mathbf{A}$ and $\mathbf{B}$ in LM. Initial compositions: $2 \times 10^{-4} \mathrm{M}$ $\mathrm{Pic}^{-}+1 \mathrm{M} \mathrm{MgSO}_{4}$ (SE) in $\mathrm{W} 1 ; 10^{-4} \mathrm{M} \mathrm{TPenA}^{+} \mathrm{TPhB}^{-}(\mathrm{SE}) ; 2 \mathrm{M}$ $\mathrm{MgSO}_{4}(\mathrm{SE})$ in $\mathrm{W} 2$.

The transfer of $\mathrm{Pic}^{-}$can be explained consulting with potential differences at the W1/LM or LM/W2 interfaces of a site (site $\boldsymbol{x}$ ) where is $x \mathrm{~cm}$ from site $\mathbf{A}, E_{\mathrm{W} 1 / \mathrm{M}, x}$ or $E_{\mathrm{W} 2 / \mathrm{M}, x}$, which was measured by using a reference electrode set in $\mathrm{W} 1$ or $\mathrm{W} 2\left(\mathrm{RE}_{\mathrm{W} 1, x}\right.$ or $\left.\mathrm{RE}_{\mathrm{W} 2, x}\right)$ and that in $\mathrm{LM}\left(\mathrm{RE}_{\mathrm{M}, x}\right)$ as the potential of $\mathrm{RE}_{\mathrm{W} 1, x}$ versus that of $\mathrm{RE}_{\mathrm{M}, x}$ or $\mathrm{RE}_{\mathrm{W} 2, x}$ versus that of $\mathrm{RE}_{\mathrm{M}, x}$, respectively.

The $E_{\mathrm{W} 1 / \mathrm{M}, x}$ or $E_{\mathrm{W} 2 / \mathrm{M}, x}$ was measured $3 \mathrm{~h}$ after the application of $E_{\mathrm{M}(\mathrm{A}-\mathrm{B})}$ of $1 \mathrm{~V}$ between sites $\mathbf{A}$ and $\mathbf{B}$ in LM, and it was found that $E_{\mathrm{W} 1 / \mathrm{M}, x}$ or $E_{\mathrm{W} 2 / \mathrm{M}, x}$ changed almost linearly with the distance from site $\mathbf{A}$ except parts in the vicinities of sites $\mathbf{A}$ and $\mathbf{B}$ where resistances in LM were small because of the transfer of ions from $\mathrm{W} 1$ or $\mathrm{W} 2$ to LM. The change of $E_{\mathrm{W} 1 / \mathrm{M}, x}$ or $E_{\mathrm{W} 2 / \mathrm{M}, x}$ can be understood as follows: The potentials inside $\mathrm{W} 1$ and $\mathrm{W} 2$ are considered to be homogeneous even when $E_{\mathrm{M}(\mathrm{A}-\mathrm{B})}$ is applied in LM, because $\mathrm{W} 1$ and $\mathrm{W} 2$ contain high concentrations of electrolytes ( $1 \mathrm{M}$ and $2 \mathrm{M} \mathrm{MgSO}_{4}$, respectively). On the other hand, the potential gradient may be generated between sites $\mathbf{A}$ and $\mathbf{B}$ in LM by the application of $E_{\mathrm{M}(\mathrm{A}-\mathrm{B})}$, because the concentration of the electrolyte $\left(\mathrm{TPenA}^{+} \mathrm{TPhB}^{-}\right.$) in LM is dilute as $10^{-4} \mathrm{M}$. Therefore, $E_{\mathrm{W} 1 / \mathrm{M} x}$ or $E_{\mathrm{W} 2 / \mathrm{M}, x}$, which is the difference between the potential in W1 or W2 and that in LM, depends on the distance of site $\boldsymbol{x}$ from site $\mathbf{A}$.

In the present case, $E_{\mathrm{W} 1 / \mathrm{M}, \mathrm{C}}$ or $E_{\mathrm{W} 2 / \mathrm{M}, \mathrm{C}}$ at site $\mathbf{C}$ settled to a potential close to the standard potential for the transfer of $\mathrm{Pic}^{-}$at the $\mathrm{W} / \mathrm{DCE}$ interface $\left(0.01 \mathrm{~V}\right.$ versus TPhE). Since the $E_{\mathrm{W} 1 / \mathrm{M} x}$ in the region between sites $\mathbf{A}$ and $\mathbf{C}$ was more negative than $0.01 \mathrm{~V}, \mathrm{Pic}^{-}$ in $\mathrm{W} 1$ in this region transferred into LM. Though $\mathrm{Pic}^{-}$in $\mathrm{LM}$ between sites $\mathbf{C}$ and $\mathbf{B}$ was expected to transfer into W2 if $\mathrm{Pic}^{-}$ existed in LM since the $E_{\mathrm{W} 2 / \mathrm{M} x}$ in this region was more positive than $0.01 \mathrm{~V}, \mathrm{Pic}^{-}$did not exist in this region in $\mathrm{LM}$ in the present experiment. Therefore, $\mathrm{Pic}^{-}$transferred only in a narrow region around site $\mathbf{C}$.

The result introduced here might endow some ideas useful for the elucidation of phenomena at membranes including biomembranes. In this connection, another type of "parallel transport" realized by applying potential difference between two sites in W1 or W2 phase was introduced in Ref. 44.

\section{Conclusion}

Some examples of biomimetic reactions observed at the $\mathrm{W} / \mathrm{O}$ interface or artificial membrane investigated by the group of present authors were introduced in this article.

Many works other than those introduced here have been carried out by many authors by using artificial systems such as the W/O interface or LM systems in order to mimic and/or elucidate the biologically or physiologically important reactions as follows;

1) Facilitation of ion transfer reactions at the $\mathrm{W} / \mathrm{O}$ interface by ionophores in $\mathrm{O}^{46-48}$ or surfactants adsorbed at the interface. ${ }^{49}$

2) Electron transfer at the $\mathrm{W} / \mathrm{O}$ interface $\mathrm{e}^{50-52}$ and its coupling with ion transfer. ${ }^{53}$

3) Transfers of drugs at the $\mathrm{W} / \mathrm{O}$ interface and their mechanisms. ${ }^{54,55}$

4) Ion transfer at the $\mathrm{W} / \mathrm{O}$ interface in the presence of phospholipid adsorbed at the interface. ${ }^{56-59}$

5) Electron transfer at the $\mathrm{W} / \mathrm{O}$ interface in the presence of porphyrin, protein, enzyme or metal nano-particle adsorbed at the interface. ${ }^{60-64}$

6) Redox reactions of photo-excited species at the $\mathrm{W} / \mathrm{O}$ interface. ${ }^{65-67}$

7) Ion transport through a BLM modified by various membrane proteines. $^{68}$

8) Electron transfer through a BLM containing various redox reagents. ${ }^{39}$

In connection with the above-described subjects, there are reviews on charge transfers at the $\mathrm{W} / \mathrm{O}$ interface written in Japanese. ${ }^{69,70}$

Since the compositions of artificial systems are known and simple, the analyses of reactions observed with the artificial systems might be easy. Therefore, the authors consider that the results of the analyses might give new concepts or view-points useful for the elucidation of the reactions at biomembranes.

\section{References}

1. J. Koryta, Ions, electrodes, and membranes, John Wiley \& Sons, New York, Chap. 3 (1982).

2. A. G. Volkov and D. W. Deamer eds., Liquid-liquid interfaces. Theory and methods, CRC, New York, Chaps. 13, 14, 16-18 (1996).

3. A. G. Volkov ed., Liquid interfaces in chemical, biological and pharmaceutical applications, Marcel Dekker, New York, Chaps. 5, 8, 19-33 (2001).

4. F. Raymond, D. Fermin, H. J. Lee, and H. H. Girault, Electrochim. Acta, 45, 2647 (2000).

5. A. G. Volkov ed., Interfacial catalysis, Marcel Dekker, New York, Chaps. 1, 1523 (2003).

6. H. Watarai, N. Teramae, and T. Sawada eds., Interfacial Nanochemistry. Molecular science and engineering at liquid-liquid interfaces, Kluwer Academic/Plenum Press, New York, Chaps. 6, 7, 11, 13, 14 (2005).

7. J. Koryta, P. Vanýsek, and M. Březina, J. Electroanal. Chem., 67, 263 (1976).

8. Z. Samec, V. Mareček, J. Weber, and D. Homolka, J. Electroanal. Chem., 99, 385 (1979).

9. S. Kihara, M. Suzuki, K. Maeda, K. Ogura, S. Umetani, M. Sugiyama, and M. Matsui, Anal. Chem., 58, 2954 (1986).

10. Z. Samec, V. Mareček, and J. Weber, J. Electroanal. Chem., 100, 841 (1979).

11. M. D. Osborne, Y. Shao, C. M. Pereira, and H. H. Girault, J. Electroanal. Chem., 364, 155 (1994).

12. H. Ohde, A. Uehara, Y. Yoshida, K. Maeda, and S. Kihara, J. Electroanal. Chem., 496, 110 (2001).

13. Y. Kitatsuji, Z. Yoshida, H. Kudo, and S. Kihara, J. Electroanal. Chem., 520, 133 (2002).

14. A. J. Parker, Chem. Rev., 69, 1 (1969).

15. Y. Yoshida, Z. Yoshida, H. Aoyagi, Y. Kitatsuji, A. Uehara, and S. Kihara, Anal. Chim. Acta, 452, 149 (2002).

16. M. Kasuno, A. Uehara, N. Ichieda, T. Kitano, K. Banu, and S. Kihara, J. Electroanal. Chem., 579, 223 (2005).

17. T. Okugaki, M. Kasuno, K. Maeda, and S. Kihara, J. Electroanal. Chem., 639, 67 (2010).

18. W. S. Caughey, Adv. Chem. Ser., 100, 248 (1971)

19. R. E. Stenkamp, Chem. Rev., 94, 715 (1994).

20. B. J. Wallar and J. D. Lipscomb, Chem. Rev., 96, 2625 (1996). 
21. P. Mottier, E. Gremaud, P. A. Guy, and R. J. Turesky, Anal. Biochem., 301, 128 (2002).

22. A. S. Csallany and H. H. Draper, Arch. Biochem. Biophys., 100, 335 (1963).

23. G. J. Wilson, C. Y. Lin, and R. D. Webster, J. Phys. Chem. B, 110, 11540 (2006)

24. S. B. Lee, C. Y. Lin, P. M. W. Gill, and R. D. Webster, J. Org. Chem., 70, 10466 (2005).

25. L. L. Williams and R. D. Webster, J. Am. Chem. Soc., 126, 12441 (2004).

26. H. Ohde, K. Maeda, Y. Yoshida, and S. Kihara, Electrochim. Acta, 44, 23 (1998)

27. U. Brandt, Biochim. Biophys. Acta, 1318, 79 (1997).

28. L. L. Miller and J. R. Valentine, J. Am. Chem. Soc., 110, 3982 (1988).

29. S. Fukuzumi, S. Koumitsu, K. Hironaka, and T. Tanaka, J. Am. Chem. Soc., 109, 305 (1987).

30. H. Ohde, K. Maeda, Y. Yoshida, and S. Kihara, J. Electroanal. Chem., 483, 108 (2000).

31. R. B. Gennis, Science, 280, 1712 (1998).

32. V. Chepuri, L. Lemieux, D. C.-T. Au, and R. B. Gennis, J. Biol. Chem., 265, 11185 (1990)

33. L. L. Ingraham and D. L. Mayer, Biochemistry of dioxygen, Plenum, New York, Chaps. 1-4 (1985)

34. B. Alberts, D. Bray, J. Lewis, M. Raff, K. Roberts, and J. D. Watson, Molecular biology of the cell, 3rd ed., Garland, New York, Chap. 14 (1994).

35. K. Maeda, M. Nishihara, H. Ohde, and S. Kihara, Anal. Sci., 14, 85 (1998).

36. J. March, Advanced organic chemistry, 4th ed., John Wiley \& Sons, New York, p. 1175 (1992)

37. R. B. Gennis, Biomembranes, Springer Verlag, Tokyo, Chap. 7 (1990).

38. O. Shirai, S. Kihara, Y. Yoshida, and M. Matsui, J. Electroanal. Chem., 389, 61 (1995).

39. H. Shiba, K. Maeda, N. Ichieda, M. Kasuno, Y. Yoshida, O. Shirai, and S. Kihara, J. Electroanal. Chem., 556, 1 (2003).

40. S. Kihara and K. Maeda, Prog. Surf. Sci., 47(1-2), 1 (1994).

41. K. Maeda, W. Hyogo, S. Nagami, and S. Kihara, Bull. Chem. Soc. Jpn., 70, 1505 (1997).

42. C. Miller, Ion channel reconstruction, Plenum Press, New York (1986).

43. D. Sakmann and E. Neher, Single-channel recording, Plenum Press, New York, Chaps. 6, 9 (1983).

44. N. Kurauchi, Y. Yoshida, N. Ichieda, H. Ohde, O. Shirai, K. Maeda, and S. Kihara, J. Electroanal. Chem., 496, 118 (2001)
45. N. Kurauchi, Y. Yoshida, N. Ichieda, M. Kasuno, K. Banu, K. Maeda, and S. Kihara, J. Electroanal. Chem., 526, 101 (2002).

46. M. Senda, T. Kakiuchi, and T. Osakai, Electrochim. Acta, 36, 253 (1991).

47. N. Teramae, S. Nishizawa, A. Yamaguchi, and T. Uchida, p. 233 in Ref. 6.

48. S. A. Dassie and A. M. Barruzi, J. Electroanal. Chem., 492, 94 (2000).

49. Z. Yoshida and S. Kihara, J. Electroanal. Chem., 227, 171 (1987).

50. Z. Samec, V. Mareček, and J. Weber, J. Electroanal. Chem., 103, 11 (1979).

51. T. Osakai and H. Hotta, p. 171 in Ref. 6.

52. D. J. Fermín, H. Jensen, and H. H. Girault, Interfacial kinetics and mass transport (Ed. E. J. Calvo), Wiley-VCH, Weinheim, p. 360 (2003).

53. T. Kakiuchi, Electrochim. Acta, 40, 2999 (1995).

54. M. Senda, Y. Kubota, and H. Katano, p. 683 in Ref. 3.

55. G. Bouchard, P.-A. Carrupt, B. Testa, V. Gobry, and H. H. Girault, Chem. Eur. J., 8, 3478 (2002).

56. T. Kakiuchi, p. 317 in Ref. 2.

57. J. A. Manzanares, R. M. Allen, and K. Kontturi, J. Electroanal. Chem., 483, 188 (2000).

58. Z. Samec, A. Trojánek, and H. H. Girault, Electrochem. Commun., 5, 98 (2003).

59. K. Maeda, T. Maekawa, Y. Yoshida, T. Okugaki, S. Kihara, and V. Mareček, J. Electroanal. Chem., 619-620, 53 (2008).

60. A. Trojánek, J. Langmaier, B. Su, H. H. Girault, and Z. Samec, Electrochem. Commun., 11, 1940 (2009).

61. T. Osakai, Y. Yuguchi, E. Gohara, and H. Katano, Langmuir, 26, 11530 (2010).

62. Y. Sasaki, T. Sugihara, and T. Osakai, Anal. Biochem., 417, 129 (2011).

63. M. A. Méndez, R. Partovi-Nia, I. Hatay, B. Su, P. Ge, A. Olaya, N. Younan, M. Hojeij, and H. H. Girault, Phys. Chem. Chem. Phys., 12, 15163 (2010).

64. D. Schaming, M. Hojeij, N. Younan, H. Nagatani, H. J. Lee, and H. H. Girault, Phys. Chem. Chem. Phys., 13, 17704 (2011)

65. H. Jensen, D. J. Fermín, and H. H. Girault, Phys. Chem. Chem. Phys., 3, 2503 (2001).

66. R. Lahtinen, H. Jensen, and D. J. Fermín, p. 611 in Ref. 5.

67. D. Schaming, I. Hatay, F. Cortez, A. Olaya, M. A. Méndez, P. Y. Ge, H. Ding, and H. H. Girault, Chimia, 65, 356 (2011).

68. O. Shirai, Y. Yoshida, and S. Kihara, Anal. Bioanal. Chem., 386, 494 (2006)

69. K. Maeda, Bunseki, 2002, 382 [in Japanese].

70. T. Osakai and H. Katano, Bunseki Kagaku, 54, 251 (2005) [in Japanese]. 